\title{
Biogenic, urban, and wildfire influences on the molecular composition of dissolved organic compounds in cloud water
}

\author{
Ryan D. Cook ${ }^{1, *}$, Ying-Hsuan Lin ${ }^{1,2, a,{ }^{*}}$, Zhuoyu Peng ${ }^{1, b}$, Eric Boone ${ }^{1, \mathrm{c}}$, Rosalie K. Chu ${ }^{3}$, James E. Dukett ${ }^{4}$, \\ Matthew J. Gunsch ${ }^{1}$, Wuliang Zhang ${ }^{1, d}$, Nikola Tolic ${ }^{3}$, Alexander Laskin ${ }^{3, e}$, and Kerri A. Pratt ${ }^{1,5}$ \\ ${ }^{1}$ Department of Chemistry, University of Michigan, Ann Arbor, MI, USA \\ ${ }^{2}$ Michigan Society of Fellows, University of Michigan, Ann Arbor, MI, USA \\ ${ }^{3}$ Environmental Molecular Sciences Laboratory, Pacific Northwest National Laboratory, Richland, WA, USA \\ ${ }^{4}$ Adirondack Lake Survey Corporation, Ray Brook, NY, USA \\ ${ }^{5}$ Department of Earth \& Environmental Sciences, University of Michigan, Ann Arbor, MI, USA \\ a now at: Department of Environmental Sciences, University of California, Riverside, Riverside, CA, USA \\ ${ }^{b}$ now at: Department of Chemistry, University of Washington, Seattle, WA, USA \\ ${ }^{c}$ now at: College of Veterinary Medicine, Purdue University, West Lafayette, IN, USA \\ dnow at: Department of Chemistry, Northwestern University, Evanston, IL, USA \\ e now at: Department of Chemistry, Purdue University, West Lafayette, IN, USA \\ *These authors contributed equally to this work.
}

Correspondence: Kerri A. Pratt (prattka@umich.edu)

Received: 4 July 2017 - Discussion started: 22 August 2017

Revised: 28 October 2017 - Accepted: 2 November 2017 - Published: 21 December 2017

\begin{abstract}
Organic aerosol formation and transformation occurs within aqueous aerosol and cloud droplets, yet little is known about the composition of high molecular weight organic compounds in cloud water. Cloud water samples collected at Whiteface Mountain, New York, during AugustSeptember 2014 were analyzed by ultra-high-resolution mass spectrometry to investigate the molecular composition of dissolved organic carbon, with a focus on sulfur- and nitrogen-containing compounds. Organic molecular composition was evaluated in the context of cloud water inorganic ion concentrations, $\mathrm{pH}$, and total organic carbon concentrations to gain insights into the sources and aqueous-phase processes of the observed high molecular weight organic compounds. Cloud water acidity was positively correlated with the average oxygen : carbon ratio of the organic constituents, suggesting the possibility for aqueous acid-catalyzed (prior to cloud droplet activation or during/after cloud droplet evaporation) and/or radical (within cloud droplets) oxidation processes. Many tracer compounds recently identified in laboratory studies of bulk aqueous-phase reactions were identified in the cloud water. Organosulfate compounds, with both biogenic and anthropogenic volatile organic compound precur-
\end{abstract}

sors, were detected for cloud water samples influenced by air masses that had traveled over forested and populated areas. Oxidation products of long-chain $\left(\mathrm{C}_{10-12}\right)$ alkane precursors were detected during urban influence. Influence of Canadian wildfires resulted in increased numbers of identified sulfur-containing compounds and oligomeric species, including those formed through aqueous-phase reactions involving methylglyoxal. Light-absorbing aqueous-phase products of syringol and guaiacol oxidation were observed in the wildfire-influenced samples, and dinitroaromatic compounds were observed in all cloud water samples (wildfire, biogenic, and urban-influenced). Overall, the cloud water molecular composition depended on air mass source influence and reflected aqueous-phase reactions involving biogenic, urban, and biomass burning precursors.

\section{Introduction}

Aqueous reactions have been suggested as an important source of high molecular weight organic matter in the atmosphere (Ervens et al., 2015; Herrmann et al., 2015). Similar 
to sulfate formation upon dissolution and oxidation of $\mathrm{SO}_{2}$ in cloud droplets (Mohnen and Kadlecek, 1989), water-soluble organic gases can also be incorporated into cloud droplets and undergo aqueous reactions (Blando and Turpin, 2000) depending on their solubility (Ervens et al., 2011). Modeling has shown that including cloud processing reactions improves prediction of secondary organic aerosol (SOA) mass concentrations (Carlton et al., 2008). However, there is substantial inconsistency between the chemical composition of laboratory-generated and ambient organic aerosol, in part likely due to aqueous processing (Chen et al., 2015). Potential products of aqueous processing include carboxylic acids, esters, organosulfur compounds, polyols, amines, amino acids, and highly oxygenated oligomeric species (Blando and Turpin, 2000; Ervens et al., 2011). However, only limited ambient evidence of cloud processing involving high molecular weight organic compounds has been reported (Boone et al., 2015; Feng and Möller, 2004; Lee et al., 2011, 2012; Pratt et al., 2013; Sagona et al., 2014; van Pinxteren et al., 2016; Zhao et al., 2013). A recent review found that more than $50 \%$ of organic matter in fog and cloud water remains unspeciated (Herckes et al., 2013). Therefore, examination of high molecular weight organic compounds present in cloud water is crucial to improve our current understanding of the complex multiphase chemical processes leading to SOA formation and transformation.

Laboratory studies have shown that aqueous-phase reactions can lead to the formation of organonitrate and organosulfate compounds (Darer et al., 2011; Minerath et al., 2008; Minerath and Elrod, 2009; Perri et al., 2010). Organosulfates are suggested to be formed from acidcatalyzed reactive uptake of epoxides onto sulfate aerosol (Surratt et al., 2010), as well as in-cloud radical-radical reactions involving sulfate radicals (Nozière et al., 2010; Perri et al., 2010; Schindelka et al., 2013). Isoprene- and monoterpene-derived organosulfates have been observed in cloud water over the southeastern US (Boone et al., 2015; Pratt et al., 2013). Modeling suggests that organosulfate formation most commonly occurs in aqueous aerosol rather than in cloud droplets (McNeill et al., 2012). Evidence of tertiary organosulfate hydrolysis in cloud water was observed in the southeast US when cloud water composition was compared to below-cloud aqueous aerosol, showing another cloud processing pathway (Boone et al., 2015).

Aqueous-phase processes may also produce high molecular weight compounds, such as oligomers (Ervens et al., 2011). Laboratory studies have shown the production of oligomers in bulk aqueous solutions from the photochemical oxidation of glyoxal, methylglyoxal, pyruvic acid, and methacrolein (Ervens et al., 2011). Oligomers have been observed in ambient cloud water (Boone et al., 2015; Pratt et al., 2013; Zhao et al., 2013); however, oligomer formation is expected to be favored in aqueous aerosol, compared to cloud droplets, due to increased self-reaction rates (Ervens et al., 2011). Yet, with few studies reporting the molecular compo- sition of high molecular weight compounds, it is difficult to assess the potential importance of these aqueous-phase derived compounds and their impacts on SOA composition and wet deposition to ecosystems (Hallquist et al., 2009).

In this work, cloud water samples were collected at Whiteface Mountain, NY, during August-September 2014 to investigate the influence of various sources and aqueous-phase reactions on the molecular composition of dissolved organic compounds. It is important to note that the molecular composition of the cloud water reflects both the precursor aerosol and any aqueous-phase processing that occurred within the cloud droplets, as well as within the aqueous aerosol prior to cloud droplet activation and following cloud droplet evaporation. An in-depth summary of Whiteface Mountain cloud water studies has been published elsewhere (Schwab et al., 2016a). Whiteface Mountain cloud water is more acidic than rainwater, with higher sulfate and nitrate concentrations (Aleksic et al., 2009), which are attributed to fossil fuel combustion (Dukett et al., 2011). Cloud deposition of total soluble sulfur accounts for $80-90 \%$ of total sulfur deposition during June-September (Baumgardner et al., 2003). The cloud water samples were analyzed by electrospray ionization (ESI) coupled to Fourier transform ion cyclotron resonance mass spectrometry (FTICR-MS) in negative ion mode to characterize high molecular weight oxidized organic compounds. Nitrogen-containing, sulfurcontaining, and oxygenated organic compounds (CHNO, CHNOS, CHOS, and $\mathrm{CHO}$ ) were identified in the cloud water and examined in the context of inorganic ion concentrations, $\mathrm{pH}$, and total organic carbon (TOC) concentrations. Identified high molecular weight compounds were compared to lists of molecular tracers of aqueous-phase reactions, identified in previous laboratory studies, to gain further insights into the aqueous-phase processing of biogenic, urban, and wildfire-influenced air masses.

\section{Experimental}

\subsection{Sampling collection and analysis for inorganic ions, pH, and TOC}

Cloud water samples were collected during AugustSeptember 2014 at Whiteface Mountain $\left(44.3659^{\circ} \mathrm{N}\right.$, $73.9026^{\circ} \mathrm{W}$; summit observatory $1483 \mathrm{~m}$ above mean sea level in the Adirondack Mountains in New York. An indepth site description is published elsewhere (Schwab et al., 2016b). Sampling times are provided in Table 1. Cloud water collection and analysis efforts by the Adirondack Lake Survey Corporation (ALSC) closely follow the original guidelines established by the EPA Clean Air Status and Trends Network (CASTNET) program in 1994. An omni-direction passive collector (Aleksic and Dukett, 2010) collected cloud water samples when the following conditions were met: cloud liquid water content $>0.05 \mathrm{~g} \mathrm{~m}^{-3}$ (to indicate the pres- 
Table 1. Summary of the sampling times, as well as inorganic ion concentrations, $\mathrm{pH}$, and TOC concentrations, for cloud water samples from the Whiteface Mountain Observatory. Cloud water samples were collected with $3 \mathrm{~h}$ resolution (local time: EDT). Values below the method limit of detection for $\mathrm{Na}^{+}$are noted as "bdl". The $95 \%$ confidence intervals are shown for August-September 2014 averages.

\begin{tabular}{|c|c|c|c|c|c|c|c|c|c|c|c|c|}
\hline Event & $\begin{array}{l}\text { Sample } \\
\text { ID }\end{array}$ & $\begin{array}{l}\text { Sampling start } \\
\text { time }\end{array}$ & $\begin{array}{r}\mathrm{SO}_{4}^{2-} \\
\mu \mathrm{M}\end{array}$ & $\begin{array}{r}\mathrm{NO}_{3}^{-} \\
\mu \mathrm{M}\end{array}$ & $\begin{array}{l}\mathrm{Cl}^{-} \\
\mu \mathrm{M}\end{array}$ & $\begin{array}{r}\mathrm{Ca}^{2+} \\
\mu \mathrm{M}\end{array}$ & $\begin{array}{c}\mathrm{Mg}^{2+} \\
\mu \mathrm{M}\end{array}$ & $\begin{array}{l}\mathrm{Na}^{+} \\
\mu \mathrm{M}\end{array}$ & $\begin{array}{l}\mathrm{K}^{+} \\
\mu \mathrm{M}\end{array}$ & $\begin{array}{r}\mathrm{NH}_{4}^{+} \\
\mu \mathrm{M}\end{array}$ & $\mathrm{pH}$ & $\begin{array}{c}\mathrm{TOC} \\
\mathrm{mg} \mathrm{L}^{-1}\end{array}$ \\
\hline \multirow{3}{*}{ Biogenic } & A1 & 16 Aug 2014 18:00 & 4.6 & 4.9 & 0.3 & 1.6 & 0.8 & bdl & 0.45 & 7.6 & 5.25 & 0.73 \\
\hline & $\mathrm{A} 2$ & 17 Aug 2014 06:00 & 9.7 & 6.3 & 0.3 & 0.7 & 0.4 & bdl & 0.30 & 9.2 & 4.79 & 1.46 \\
\hline & $\mathrm{A} 3$ & 17 Aug 2014 18:00 & 3.6 & 3.2 & 0.5 & 0.5 & 0.3 & bdl & 0.37 & 6.7 & 4.94 & 2.16 \\
\hline \multirow{2}{*}{ Urban } & B1 & 2 Sep 2014 06:00 & 69.4 & 30.7 & 2.7 & 2.2 & 0.8 & 4.3 & 0.87 & 79.5 & 4.18 & 2.11 \\
\hline & $\mathrm{B} 2$ & 2 Sep 2014 18:00 & 10.1 & 10.2 & 0.7 & 0.3 & 0.2 & bdl & 0.02 & 12.7 & 4.86 & 1.19 \\
\hline \multirow{3}{*}{ Wildfire } & $\mathrm{C} 1$ & 4 Aug 2014 18:00 & 100.1 & 158.3 & 6.5 & 18.0 & 6.2 & 0.9 & 5.13 & 311.8 & 4.05 & 16.6 \\
\hline & $\mathrm{C} 2$ & 5 Aug 2014 06:00 & 103.2 & 176.6 & 7.9 & 20.8 & 6.6 & 1.3 & 5.38 & 373.5 & 4.10 & 16.6 \\
\hline & $\mathrm{C} 3$ & 6 Aug 2014 18:00 & 9.4 & 13.3 & 1.3 & 5.3 & 1.1 & 0.4 & 1.30 & 33.0 & 4.54 & 7.86 \\
\hline \multicolumn{3}{|c|}{ August-September 2014 average values } & $32 \pm 9$ & $38 \pm 12$ & $9 \pm 8$ & $7 \pm 3$ & $2 \pm 1$ & $11 \pm 2$ & $1.6 \pm 0.5$ & $66 \pm 11$ & $4.8 \pm 0.1$ & $3.1 \pm 0.8$ \\
\hline
\end{tabular}

ence of clouds), temperature $>2{ }^{\circ} \mathrm{C}$ (to avoid freezing of the sampler), wind speed $>2 \mathrm{~ms}^{-1}$ (to assist with cloud water collection by the sampler), and no precipitation (to isolate cloud droplets only). A field blank was collected at the summit of Whiteface Mountain by pouring deionized water into a sample container. Routine analyses of inorganic ions $\left(\mathrm{SO}_{4}^{2-}, \mathrm{NO}_{3}^{-}, \mathrm{Cl}^{-}, \mathrm{Ca}^{2+}, \mathrm{Mg}^{2+}, \mathrm{Na}^{+}, \mathrm{K}^{+}, \mathrm{NH}_{4}^{+}\right), \mathrm{pH}$, and TOC are performed by the ALSC, as described elsewhere (Baumgardner et al., 2003). Average August-September values from 2010 to 2015 are presented in Table S1 in the Supplement, and the data can be accessed at http://www. adirondacklakessurvey.org/.

\subsection{ESI-FTICR-MS analysis}

Cloud water samples and a field blank for mass spectrometric analysis were preconcentrated using solid-phase extraction (Strata ${ }^{\mathrm{TM}}-\mathrm{X}$ polymeric solid-phase extraction sorbents), according to the method of Zhao et al. (2013) to enhance detection and to reduce potential matrix effects from inorganic ions. TOC concentrations of each cloud water sample after SPE ranged from 15 to $398 \mathrm{mg} \mathrm{L}^{-1}$ (Table S2), with original TOC concentrations shown in Table 1. It should be noted that lower molecular weight organic compounds (i.e., most isoprene oxidation products), including some organosulfates, are expected to be removed during extraction (Zhao et al., 2013).

A $12 \mathrm{~T}$ Bruker solariX FTICR mass spectrometer (Billerica, MA) was used to collect ultra-high-resolution mass spectra of the cloud water samples. The detailed instrument parameters and analysis procedures, optimized during dissolved organic matter experiments, have been described previously (Kujawinski and Behn, 2006; Minor et al., 2012; Tfaily et al., 2015). A standard Bruker electrospray ionization (ESI) source was used to generate negatively charged molecular ions to target analysis of oxidized organic compounds. Samples were first diluted in liquid chromatography-mass spectrometry (LC-MS) grade ace- tonitrile to similar TOC concentrations 15 to $45 \mathrm{mg} \mathrm{L}^{-1}$ and then introduced through a syringe pump at a flow rate of $3.0 \mu \mathrm{L} \mathrm{min}{ }^{-1}$ through a $200 \mu \mathrm{m}$ ID fused silica transfer tube. Experimental conditions were as follows: needle voltage, $+4.5 \mathrm{kV}$; Q1 set to $100 \mathrm{~m} / z$; heated glass coated metal capillary operated at $180^{\circ} \mathrm{C}$; and the ion accumulation time was adjusted for best spectral quality. These parameters were chosen based on previous experiments that optimized complex organic matter characterization (Tfaily et al., 2011, 2012, 2013). A total of 200 individual scans were co-added, and the average resolving power $(\mathrm{m} / \Delta \mathrm{m})$ was $>450000$ at $451 \mathrm{Da}$. Mass spectra were calibrated by two dissolved organic matter homologous series separated by $14 \mathrm{Da}\left(-\mathrm{CH}_{2}\right.$ groups), and the mass accuracy was calculated to be $<1 \mathrm{ppm}$ for singly charged ions ranging across the mass spectral distribution $(\mathrm{m} / \mathrm{z} 100-1000)$. A solvent blank of acetonitrile was also analyzed. A threshold was set to assign peaks with $\mathrm{S} / \mathrm{N}>15$ from the spectra of all samples. Only sample ion peaks with intensities at least 100 times higher than those in either the blank or acetonitrile were retained for further data analysis. Assignments were made with elements limited to $\mathrm{C}, \mathrm{H}, \mathrm{O}, \mathrm{N}$, and $\mathrm{S}$, with $\mathrm{S}=0-1, \mathrm{~N}=0-2$, and the minimum number of $\mathrm{O}$ atoms per detected $\mathrm{S}$ or $\mathrm{N}$ was set to be three. Assignments were limited to mass error of $\pm 0.5 \mathrm{ppm}$. All ${ }^{13} \mathrm{C}$ isotopic peaks were removed. These conservative limits of data processing and assignments resulted in approximately 430-2300 peaks identified per sample (up to $\sim 60 \%$ of the total number of detected peaks, after removal of ${ }^{13} \mathrm{C}$ and blank peaks). A complete list of assigned peaks is provided in Table S3. For individual elemental composition $\mathrm{C}_{c} \mathrm{H}_{h} \mathrm{~N}_{n} \mathrm{O}_{o} \mathrm{~S}_{s}$, double bond equivalents (DBEs) were determined by Eq. (1), where $c, h$, and $n$ are the number of carbon, hydrogen, and nitrogen atoms in the molecular formula, respectively.

$\mathrm{DBE}=c-h / 2+n / 2+1$ 
Sulfur and oxygen are divalent, and nitrogen is trivalent here. Therefore, the DBE calculation does not account for tetravalent and hexavalent $\mathrm{S}$ or pentavalent $\mathrm{N}$ (Mazzoleni et al., 2010).

\subsection{Backward air mass trajectory analyses}

Sources of the air masses arriving at the sampling site were evaluated using NOAA Hybrid Single-Particle Lagrangian Integrated Trajectory Model (HYSPLIT) analysis (Stein et al., 2015). The 6-day backward air mass trajectories were run from the beginning of the sample collection time at a starting height of $1500 \mathrm{~m}$ a.m.s.l., based on the Whiteface Mountain Observatory altitude $(1483 \mathrm{~m})$. Modeled mixed layer depth for each trajectory was examined to determine the influence of sources (e.g., forests and urban areas) within the atmosphere boundary layer. To investigate whether samples were likely influenced by wildfires, the NOAA Hazard Mapping System Fire and Smoke Product (http://www.ospo.noaa.gov/ Products/land/hms.html) was used along with the backward air mass trajectories. The smoke product is divided into categories (light, moderate, heavy smoke) as determined via satellite images collected using GOES, Advanced Very High Resolution Radiometer (AVHRR), and Moderate Resolution Imaging Spectroradiometer (MODIS) images.

\section{Results and discussion}

Overall, Whiteface Mountain cloud water samples show a correlation between water acidity and the average oxygento-carbon atomic ratios $(\mathrm{O}: \mathrm{C})$ of the high molecular weight compounds detected by (-) ESI-FTICR MS (Fig. 1). The average $\mathrm{pH}$ of the cloud water samples was $4.6 \pm 0.7(95 \%$ confidence interval), reflective of increasing cloud water $\mathrm{pH}$ at the site over the past several decades due to reductions in $\mathrm{SO}_{2}$ and $\mathrm{NO}_{x}$ emissions (Schwab et al., 2016a). The average $\mathrm{O}: \mathrm{C}$ ratio of the high molecular weight negative ions was $0.505 \pm 0.004$. To investigate the role of precursor sources on the identities of the dissolved organic compounds in the cloud water, samples were grouped based on backward air mass trajectories (Fig. S1 in the Supplement) apportioned to (a) biogenic (16-17 August 2014), (b) urban (2 September 2014), and (c) wildfire (4-6 August 2014) sources. The average $\mathrm{O}: \mathrm{C}$ ratios of the grouped biogenic-, urban-, and wildfire-influenced cloud water samples were $0.460 \pm 0.008$ (95\% confidence interval), $0.489 \pm 0.007$, and $0.534 \pm 0.005$, respectively. Average $\mathrm{H}: \mathrm{C}$ ratios and DBE values corresponding to each of the air masses are listed in Table S4. The following sections discuss the cloud water chemical composition as a function of air mass influence.

\subsection{Biogenic influence}

For the cloud water samples collected on 16-17 August 2014 (A1-A3, Table 1), the air mass had traveled from the Cana-

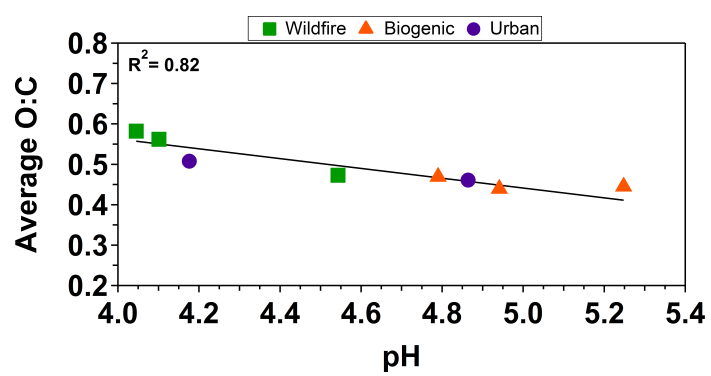

Figure 1. Correlation between cloud water $\mathrm{pH}$ and average $\mathrm{O}: \mathrm{C}$ ratio (negative ion mode, $m / z 100-1000$ ) by air mass source influence.

dian boreal forest before passing over Detroit, MI, and Buffalo, NY, prior to arrival at Whiteface Mountain (Fig. S1). The measured cloud water $\mathrm{pH}$ values were 4.79-5.25, less acidic than samples collected under greater urban or biomass burning influence, as well as the August-September 2014 average $\mathrm{pH}(4.8 \pm 0.1,95 \%$ confidence interval) (Table 1$)$. These cloud water samples had the lowest nitrate, sulfate, chloride, and ammonium concentrations compared to the other samples. Notably, the measured TOC and sulfate concentrations were $0.73-2.16 \mathrm{mg} \mathrm{L}^{-1}$ and 3.6-9.7 $\mu \mathrm{M}$, respectively, which are below the August-September 2014 averages of $3.1 \pm 0.8 \mathrm{mg} \mathrm{L}^{-1}$ and $32 \pm 9 \mu \mathrm{M}$ (Table 1), as well as the August-September 2010-2015 averages (Table S1).

Negative ion mass spectra for the A1-A3 cloud water samples are shown in Figs. 2 and S2 with nitrogencontaining, sulfur-containing, and oxygenated organic compounds (CHNO, CHNOS, CHOS, and $\mathrm{CHO}$ ) compounds highlighted. Corresponding number fractions of the assigned organic compound types, as well as the distributions of the number of carbon atoms per assigned compound, are shown in Figs. 2 and S3, as well as Table S5. For the biogenicinfluenced cloud water samples (A1-A3), CHO compounds compose $51-56 \%$, by number, of the dissolved organic species identified (Table S5). CHO compounds potentially arising from aqueous reactions were identified by comparison to laboratory studies of the aqueous photooxidation of $\alpha$-pinene oxidation products (cis-pinonic acid and the surrogate tricarballylic acid) (Aljawhary et al., 2016) and isoprene oxidation products (methyl vinyl ketone and isoprene SOA) (Nguyen et al., 2012a; Renard et al., 2015) (Table 3). CHOS and CHNOS compounds account for 14 and 7-9\%, respectively, of the measured organic compounds in the A1 and A2 samples; lower percentages were observed for sample A3 (Table S5), consistent with the lower sulfate concentration in A3 (Table 1). These biogenic-influenced cloud water samples contained several unique CHOS and CHNOS compounds with relatively low $\mathrm{O}: \mathrm{C}(0.05-0.4)$ and $\mathrm{H}: \mathrm{C}(0.7-1.1)$ ratios (Figs. 3 and $\mathrm{S} 4$ ), compared to the sulfur-containing organic compounds in other cloud water samples. These unique compounds all contained high DBE 
Table 2. Identified SOA tracers $(\mathrm{m} / \mathrm{z}$, neutral molecular formula, suggested volatile organic compound (VOC) precursor, and compound type, based on previous laboratory chamber studies) in each cloud water sample, with observed potential hydrolysis products of likely organosulfates noted.

\begin{tabular}{|c|c|c|c|c|c|}
\hline $\begin{array}{l}{[\mathrm{M}-\mathrm{H}]^{-}} \\
(m / z)\end{array}$ & $\begin{array}{l}\text { Molecular } \\
\text { formula }\end{array}$ & $\begin{array}{l}\text { VOC } \\
\text { precursors }\end{array}$ & $\begin{array}{l}\text { Compound } \\
\text { type }\end{array}$ & Observed in cloud water samples & $\begin{array}{l}\text { Observed potential } \\
\text { hydrolysis products }\end{array}$ \\
\hline 223.0282 & $\mathrm{C}_{7} \mathrm{H}_{12} \mathrm{O}_{6} \mathrm{~S}$ & \multirow{5}{*}{$\alpha$-pinene } & \multirow{21}{*}{$\begin{array}{l}\text { Monoterpene- } \\
\text { derived } \\
\text { organosulfates } \\
\text { and nitroxy- } \\
\text { organosulfates } \\
\text { (Iinuma et al., } \\
2007 a, b, 2009 \text {; } \\
\text { Nozière et al., } \\
2010 ; \text { Surratt } \\
\text { et al., 2008) }\end{array}$} & $\mathrm{B} 1, \mathrm{C} 1, \mathrm{C} 2$ & $\mathrm{C}_{7} \mathrm{H}_{12} \mathrm{O}_{3}$ \\
\hline 237.0438 & $\mathrm{C}_{8} \mathrm{H}_{14} \mathrm{O}_{6} \mathrm{~S}$ & & & $\mathrm{~A} 2, \mathrm{~B} 1, \mathrm{C} 1, \mathrm{C} 2, \mathrm{C} 3$ & - \\
\hline 279.0544 & $\mathrm{C}_{10} \mathrm{H}_{16} \mathrm{O}_{7} \mathrm{~S}$ & & & $\mathrm{~A} 1, \mathrm{~A} 2, \mathrm{~A} 3, \mathrm{~B} 1, \mathrm{~B} 2, \mathrm{C} 1, \mathrm{C} 2, \mathrm{C} 3$ & $\mathrm{C}_{10} \mathrm{H}_{16} \mathrm{O}_{4}$ \\
\hline 281.0700 & $\mathrm{C}_{10} \mathrm{H}_{18} \mathrm{O}_{7} \mathrm{~S}$ & & & $\mathrm{~A} 1, \mathrm{~A} 2, \mathrm{~A} 3, \mathrm{~B} 1, \mathrm{~B} 2, \mathrm{C} 1, \mathrm{C} 2, \mathrm{C} 3$ & $\mathrm{C}_{10} \mathrm{H}_{18} \mathrm{O}_{4}$ \\
\hline 297.0650 & $\mathrm{C}_{10} \mathrm{H}_{18} \mathrm{O}_{8} \mathrm{~S}$ & & & $\mathrm{~A} 1, \mathrm{~A} 2, \mathrm{~A} 3, \mathrm{~B} 1, \mathrm{~B} 2, \mathrm{C} 1, \mathrm{C} 2, \mathrm{C} 3$ & $\mathrm{C}_{10} \mathrm{H}_{18} \mathrm{O}_{5}$ \\
\hline 249.0802 & $\mathrm{C}_{10} \mathrm{H}_{18} \mathrm{O}_{5} \mathrm{~S}$ & \multirow{2}{*}{$\beta$-pinene } & & $\mathrm{A} 1, \mathrm{~A} 2, \mathrm{~A} 3, \mathrm{~B} 1, \mathrm{~B} 2, \mathrm{C} 1, \mathrm{C} 2, \mathrm{C} 3$ & - \\
\hline 263.0595 & $\mathrm{C}_{10} \mathrm{H}_{16} \mathrm{O}_{6} \mathrm{~S}$ & & & $\mathrm{~A} 1, \mathrm{~A} 2, \mathrm{~A} 3, \mathrm{~B} 1, \mathrm{~B} 2, \mathrm{C} 1, \mathrm{C} 2, \mathrm{C} 3$ & - \\
\hline 239.0231 & $\mathrm{C}_{7} \mathrm{H}_{12} \mathrm{O}_{7} \mathrm{~S}$ & \multirow{5}{*}{$d$-limonene } & & $\mathrm{B} 1, \mathrm{C} 1$ & $\mathrm{C}_{7} \mathrm{H}_{12} \mathrm{O}_{4}$ \\
\hline 251.0595 & $\mathrm{C}_{9} \mathrm{H}_{16} \mathrm{O}_{6} \mathrm{~S}$ & & & $\mathrm{~A} 1, \mathrm{~A} 2, \mathrm{~B} 1, \mathrm{~B} 2, \mathrm{C} 1, \mathrm{C} 2, \mathrm{C} 3$ & $\mathrm{C}_{9} \mathrm{H}_{16} \mathrm{O}_{3}$ \\
\hline 267.0545 & $\mathrm{C}_{9} \mathrm{H}_{16} \mathrm{O}_{7} \mathrm{~S}$ & & & $\mathrm{~A} 2, \mathrm{~B} 1, \mathrm{C} 1, \mathrm{C} 2, \mathrm{C} 3$ & $\mathrm{C}_{9} \mathrm{H}_{16} \mathrm{O}_{4}$ \\
\hline 279.0544 & $\mathrm{C}_{10} \mathrm{H}_{16} \mathrm{O}_{7} \mathrm{~S}$ & & & $\mathrm{~A} 1, \mathrm{~A} 2, \mathrm{~A} 3, \mathrm{~B} 1, \mathrm{~B} 2, \mathrm{C} 1, \mathrm{C} 2, \mathrm{C} 3$ & $\mathrm{C}_{10} \mathrm{H}_{16} \mathrm{O}_{4}$ \\
\hline 281.0700 & $\mathrm{C}_{10} \mathrm{H}_{18} \mathrm{O}_{7} \mathrm{~S}$ & & & $\mathrm{~A} 1, \mathrm{~A} 2, \mathrm{~A} 3, \mathrm{~B} 1, \mathrm{~B} 2, \mathrm{C} 1, \mathrm{C} 2, \mathrm{C} 3$ & $\mathrm{C}_{10} \mathrm{H}_{18} \mathrm{O}_{4}$ \\
\hline 253.0388 & $\mathrm{C}_{8} \mathrm{H}_{14} \mathrm{O}_{7} \mathrm{~S}$ & \multirow{6}{*}{$\alpha$-terpinene } & & $\mathrm{B} 1, \mathrm{C} 1, \mathrm{C} 2$ & - \\
\hline 283.0493 & $\mathrm{C}_{9} \mathrm{H}_{16} \mathrm{O}_{8} \mathrm{~S}$ & & & $\mathrm{~A} 1, \mathrm{~A} 2, \mathrm{~A} 3, \mathrm{~B} 1, \mathrm{~B} 2, \mathrm{C} 1, \mathrm{C} 2, \mathrm{C} 3$ & $\mathrm{C}_{9} \mathrm{H}_{16} \mathrm{O}_{5}$ \\
\hline 279.0544 & $\mathrm{C}_{10} \mathrm{H}_{16} \mathrm{O}_{7} \mathrm{~S}$ & & & $\mathrm{~A} 1, \mathrm{~A} 2, \mathrm{~A} 3, \mathrm{~B} 1, \mathrm{~B} 2, \mathrm{C} 1, \mathrm{C} 2, \mathrm{C} 3$ & $\mathrm{C}_{10} \mathrm{H}_{16} \mathrm{O}_{4}$ \\
\hline 281.0700 & $\mathrm{C}_{10} \mathrm{H}_{18} \mathrm{O}_{7} \mathrm{~S}$ & & & $\mathrm{~A} 1, \mathrm{~A} 2, \mathrm{~A} 3, \mathrm{~B} 1, \mathrm{~B} 2, \mathrm{C} 1, \mathrm{C} 2, \mathrm{C} 3$ & $\mathrm{C}_{10} \mathrm{H}_{18} \mathrm{O}_{4}$ \\
\hline 283.0857 & $\mathrm{C}_{10} \mathrm{H}_{20} \mathrm{O}_{7} \mathrm{~S}$ & & & $\mathrm{~A} 1, \mathrm{~A} 2, \mathrm{~A} 3, \mathrm{~B} 1, \mathrm{~B} 2, \mathrm{C} 1, \mathrm{C} 2, \mathrm{C} 3$ & $\mathrm{C}_{10} \mathrm{H}_{20} \mathrm{O}_{4}$ \\
\hline 297.0650 & $\mathrm{C}_{10} \mathrm{H}_{18} \mathrm{O}_{8} \mathrm{~S}$ & & & $\mathrm{~A} 1, \mathrm{~A} 2, \mathrm{~A} 3, \mathrm{~B} 1, \mathrm{~B} 2, \mathrm{C} 1, \mathrm{C} 2, \mathrm{C} 3$ & $\mathrm{C}_{10} \mathrm{H}_{18} \mathrm{O}_{5}$ \\
\hline 296.0446 & $\mathrm{C}_{9} \mathrm{H}_{15} \mathrm{NO}_{8} \mathrm{~S}$ & \multirow{3}{*}{ Monoterpenes } & & $\mathrm{B} 1, \mathrm{~B} 2, \mathrm{C} 1$ & $\mathrm{C}_{10} \mathrm{H}_{18} \mathrm{O}_{5}$ \\
\hline 294.0653 & $\mathrm{C}_{10} \mathrm{H}_{17} \mathrm{NO}_{7} \mathrm{~S}$ & & & $\mathrm{~A} 1, \mathrm{~A} 2, \mathrm{~A} 3, \mathrm{~B} 1, \mathrm{~B} 2, \mathrm{C} 3$ & $\mathrm{C}_{10} \mathrm{H}_{18} \mathrm{O}_{5} \mathrm{~S} ; \mathrm{C}_{10} \mathrm{H}_{17} \mathrm{NO}_{4}$ \\
\hline 342.0500 & $\mathrm{C}_{10} \mathrm{H}_{17} \mathrm{NO}_{10} \mathrm{~S}$ & & & $\mathrm{~A} 1, \mathrm{~A} 2, \mathrm{~A} 3, \mathrm{~B} 1, \mathrm{~B} 2, \mathrm{C} 1, \mathrm{C} 2, \mathrm{C} 3$ & $\mathrm{C}_{10} \mathrm{H}_{18} \mathrm{O}_{8} \mathrm{~S} ; \mathrm{C}_{10} \mathrm{H}_{17} \mathrm{NO}_{7}$ \\
\hline 209.0489 & $\mathrm{C}_{7} \mathrm{H}_{14} \mathrm{O}_{5} \mathrm{~S}$ & Dodecane & Aliphatic & $\mathrm{B} 1, \mathrm{C} 1$ & - \\
\hline 267.0545 & $\mathrm{C}_{9} \mathrm{H}_{16} \mathrm{O}_{7} \mathrm{~S}$ & Decalin/cyclodecane & organosulfates & $\mathrm{A} 2, \mathrm{~B} 1, \mathrm{C} 1, \mathrm{C} 2, \mathrm{C} 3$ & - \\
\hline 299.0806 & $\mathrm{C}_{10} \mathrm{H}_{20} \mathrm{O}_{8} \mathrm{~S}$ & Decalin & (Riva et al., & $\mathrm{B} 1, \mathrm{C} 1, \mathrm{C} 2, \mathrm{C} 3$ & $\mathrm{C}_{10} \mathrm{H}_{20} \mathrm{O}_{5}$ \\
\hline 311.0442 & $\mathrm{C}_{10} \mathrm{H}_{16} \mathrm{O}_{9} \mathrm{~S}$ & Decalin & 2016) & $\mathrm{A} 2, \mathrm{~B} 1, \mathrm{C} 1, \mathrm{C} 2, \mathrm{C} 3$ & $\mathrm{C}_{10} \mathrm{H}_{16} \mathrm{O}_{6}$ \\
\hline 307.0857 & $\mathrm{C}_{12} \mathrm{H}_{20} \mathrm{O}_{7} \mathrm{~S}$ & Dodecane & & $\mathrm{A} 1, \mathrm{~A} 2, \mathrm{~B} 1, \mathrm{~B} 2, \mathrm{C} 1, \mathrm{C} 2, \mathrm{C} 3$ & $\mathrm{C}_{12} \mathrm{H}_{20} \mathrm{O}_{4}$ \\
\hline
\end{tabular}

values ( 9 or greater for $\mathrm{C}_{16}-\mathrm{C}_{25}$ molecules), suggesting the presence of multiple double bonds or ring structures. In the Amazon, Kourtchev et al. (2016) previously found a similar subset of these unidentified CHOS compounds in SOA samples, suggesting a biogenic influence. Many organosulfates and nitrooxy-organosulfates, previously reported in laboratory studies, ambient aerosols, and cloud water as derived from monoterpene oxidation (Boone et al., 2015; Hamilton et al., 2013; Iinuma et al., 2007a, b, 2009; Kristensen et al., 2016; Kristensen and Glasius, 2011; Lin et al., 2012; Mazzoleni et al., 2012; Nguyen et al., 2012b; Nozière et al., 2010; O'Brien et al., 2014; Pratt et al., 2013; Stone et al., 2012; Surratt et al., 2008), were detected in the biogenic-influenced cloud water samples (Table 2), also consistent with monoterpene emissions along the air mass trajectories (Guenther et al., 2006). In this study, the required solid-phase extraction step precluded the detection of isoprene-derived organosulfates, which would have been removed prior to analysis. Hydrolysis products (or precursors) of most of the identified organosulfates and organonitrates were also found in the cloud water samples (Table 2), consistent with laboratory studies (Darer et al., 2011; Hu et al., 2011) and the previous field observation of organosulfate hydrolysis in cloud water (Boone et al., 2015).

CHNO compounds contributed $26 \%$, by number, in the A1 and A2 samples (Table S5). The A3 sample, characterized by less urban influence (Fig. S1), featured a greater number of CHNO compounds, as well as a higher number fraction (38\%) (Table S5). Among the CHNO compounds, unique compounds with two $\mathrm{N}$ atoms $(\sim 30 \%$ of total $\mathrm{CHNO}$ compounds) were observed in the biogenic-influenced samples (A1-A3); these dinitrogen organic compounds were diverse with $\mathrm{O}: \mathrm{C}$ 0.05-1.17, $\mathrm{H}$ : C 0.5-1.88 (Figs. 3 and S4), and DBE 4-17. Several likely dinitroaromatic compounds, including $\mathrm{C}_{6} \mathrm{H}_{6} \mathrm{~N}_{2} \mathrm{O}_{6}$ (DBE of 5), $\mathrm{C}_{7} \mathrm{H}_{6} \mathrm{~N}_{2} \mathrm{O}_{5}$ (DBE of 6), $\mathrm{C}_{7} \mathrm{H}_{6} \mathrm{~N}_{2} \mathrm{O}_{6}$ (DBE of 6), and $\mathrm{C}_{9} \mathrm{H}_{8} \mathrm{~N}_{2} \mathrm{O}_{6}$ (DBE of 7), were identified in these biogenic-influenced samples only. The formation of dinitroaromatics has been reported to originate from aqueous-phase radical nitration of mononitroaromatics (Kroflič et al., 2015). Since no possible mononitroaromatics were observed in the samples, this suggests either a different formation pathway or that complete reaction had 
A2) Biogenic

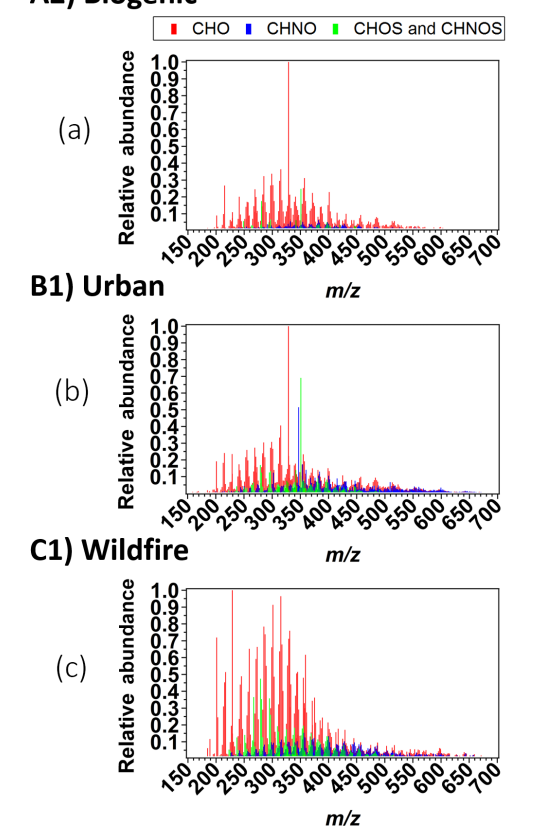

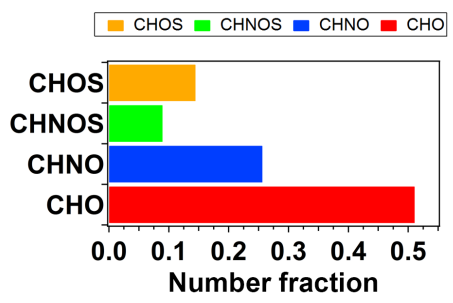
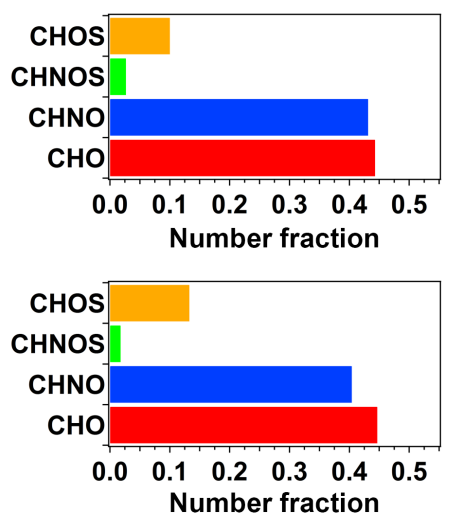
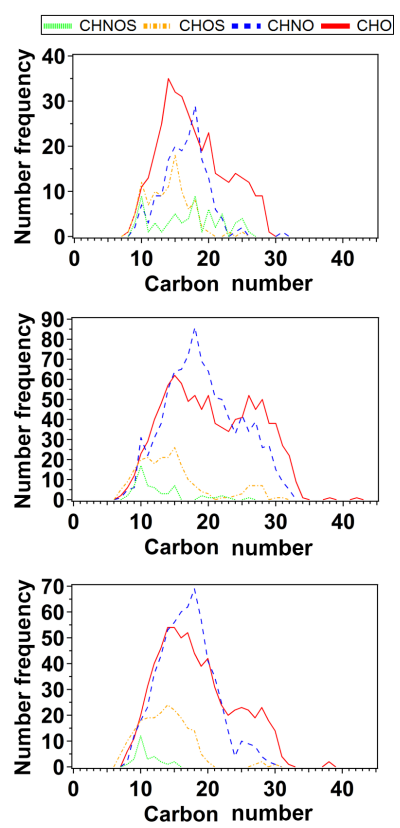

Figure 2. (-) ESI-FTICR mass spectra (left panels), compound-type number fractions (middle panels), and carbon number frequency distribution (right panels) of compound types (CHO, CHNO, CHOS, and CHNOS) for representative cloud water samples collected on (a) 17 August 2014 06:00-09:00 EDT (A2), under northern forest (biogenic) influence combined with urban pollution, (b) 2 September 2014 06:00-09:00 EDT (B1), under urban pollution influence, and (c) 4 August 2014 18:00-21:00 EDT (C1), under the influence of Canadian wildfires. Mass spectra, compound-type number fractions, and carbon number distributions for the remaining samples are shown in Figs. S2 and $\mathrm{S} 3$, respectively.

occurred. Nitroaromatics are light-absorbing brown carbon compounds, which suggests the potential climate importance of these compounds following cloud droplet evaporation (Laskin et al., 2015).

\subsection{Urban influence}

The cloud water samples collected on 2 September from 06:00 to 09:00 EDT (B1) and 18:00-21:00 EDT (B2) were characterized by significant urban influence, with air mass trajectories traveling from the southwest across multiple metropolitan areas, including Buffalo, NY, Detroit, MI, and/or Cleveland, $\mathrm{OH}$ (among others), prior to arrival at Whiteface Mountain (Fig. S1). Elevated sulfate (10.1$69.4 \mu \mathrm{M})$ and acidity (pH 4.18-4.86), but similar TOC (1.19$2.11 \mathrm{mg} \mathrm{L}^{-1}$ ), were measured for the cloud water samples, compared to the biogenic-influenced period (Table 1). The sulfate concentrations are representative of AugustSeptember 2014 averages of $32 \pm 9 \mu \mathrm{M}(95 \%$ confidence interval), as well as August-September 2010-2015 (Table S1).

The mass spectra of the B1 and B2 cloud water samples are shown in Figs. 2 and S2. A total of 2276 oxidized organic compounds were identified in the B1 sample, highlighting the diversity and complexity of the cloud water molecular composition. The $\mathrm{CHO}$ compounds were the most prevalent at $44-53 \%$, by number, similar to the other air mass influences (Table S5). CHO compounds with assignments consistent with aqueous-phase reaction products, based on laboratory studies, are noted in Table 3. Notably, CHNO compounds account for $36-43 \%$ of the identified compounds, generally much higher than the number fractions (as well as absolute numbers) observed in the biogenicinfluenced cloud water samples (Table S5). This is likely due to the influence of elevated $\mathrm{NO}_{x}$ emissions in urban locations due to fossil fuel combustion. The CHNO compounds in these samples ranged from containing 7 to 32 carbon atoms, with a median of $\mathrm{C}_{18}$ (Fig. 2). A total of $24 \%$ of the CHNO compounds, by number, in the urban-influenced samples were composed of more than 23 carbon atoms, compared to only 3 and $12 \%$ of the CHNO in the biogenic- and wildfire-influenced samples, respectively, suggesting the influence of long-chain, fossil-fuel-derived organic precursors in these urban-influenced samples. Recent cloud water studies by Boone et al. (2015) and Zhao et al. (2013) also observed significant number fractions of $\mathrm{CHNO}$ compounds; however, the $\mathrm{O}: \mathrm{C}$ and $\mathrm{H}: \mathrm{C}$ ratios of the $\mathrm{CHNO}$ compounds observed in these previous studies are not similar to those measured herein. Based on comparison with below-cloud particles, Boone et al. (2015) suggested aqueous-phase formation of the CHNO compounds, and due to wintertime sam- 

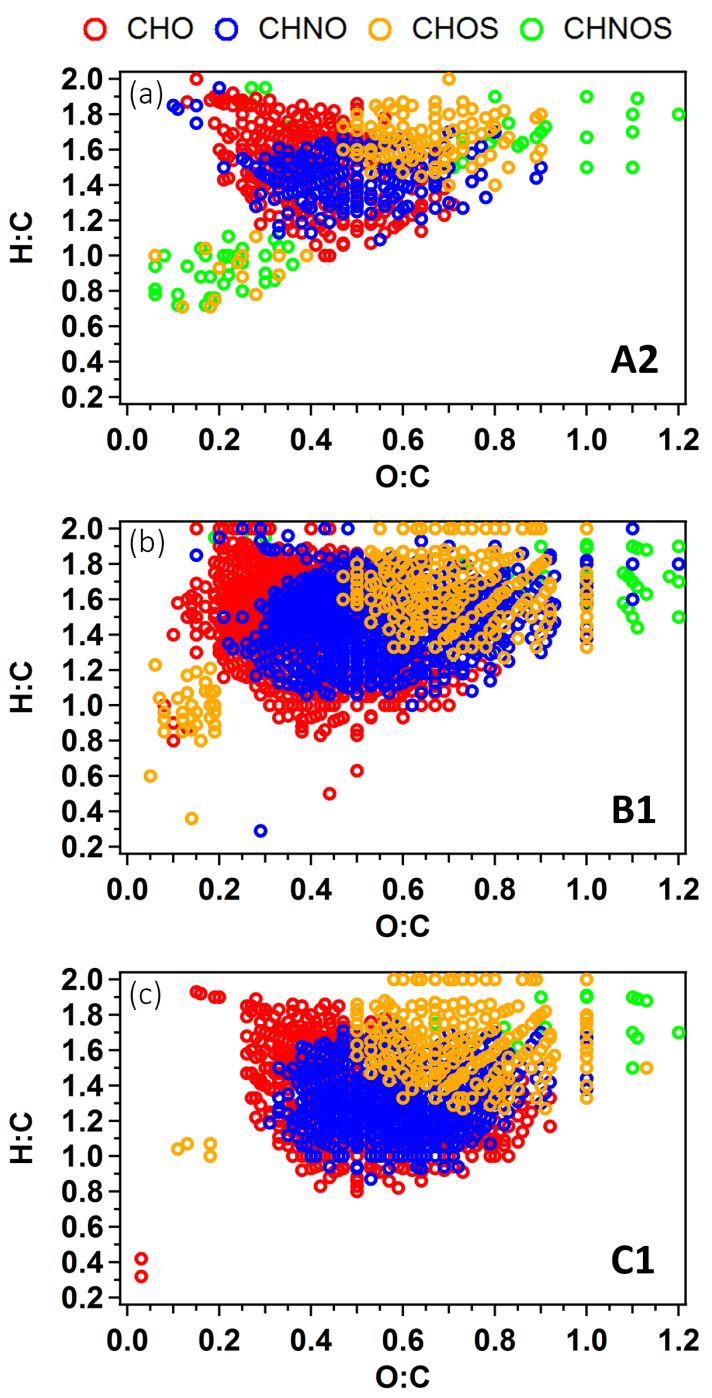

Figure 3. Van Krevelen diagrams as a function of compound type (CHO, CHNO, CHOS, and CHNOS) for the representative cloud water samples collected on (A2) 17 August 2014 06:0009:00 EDT (a), (B1) 2 September 2014 06:00-09:00 EDT (b), and (C1) 4 August 2014 18:00-21:00 EDT (c). Van Krevelen diagrams for the remaining samples are shown in Fig. S4.

pling, Zhao et al. (2013) suggested contribution from residential wood burning.

CHOS and CHNOS account for 7-10 and 3-4\%, by number, respectively, of the identified organic compounds in the urban-influenced samples (Table S5). A fraction of the CHOS compounds, unique to sample $\mathrm{B} 1$, were characterized by low $\mathrm{O}: \mathrm{C}(0.05-0.25)$ and $\mathrm{H}: \mathrm{C}(0.6-1.2)$ ratios, similar to previous cloud water observations by Zhao et al. (2013). Notably, aliphatic organosulfate species derived from photooxidation of long-chain alkane precursors $\left(\mathrm{C}_{10-12}\right)$, including dodecane, cyclodecane, and decalin, recently observed in laboratory and urban ambient aerosol studies (Riva et al., 2016; Tao et al., 2014), were detected in the B1 cloud water
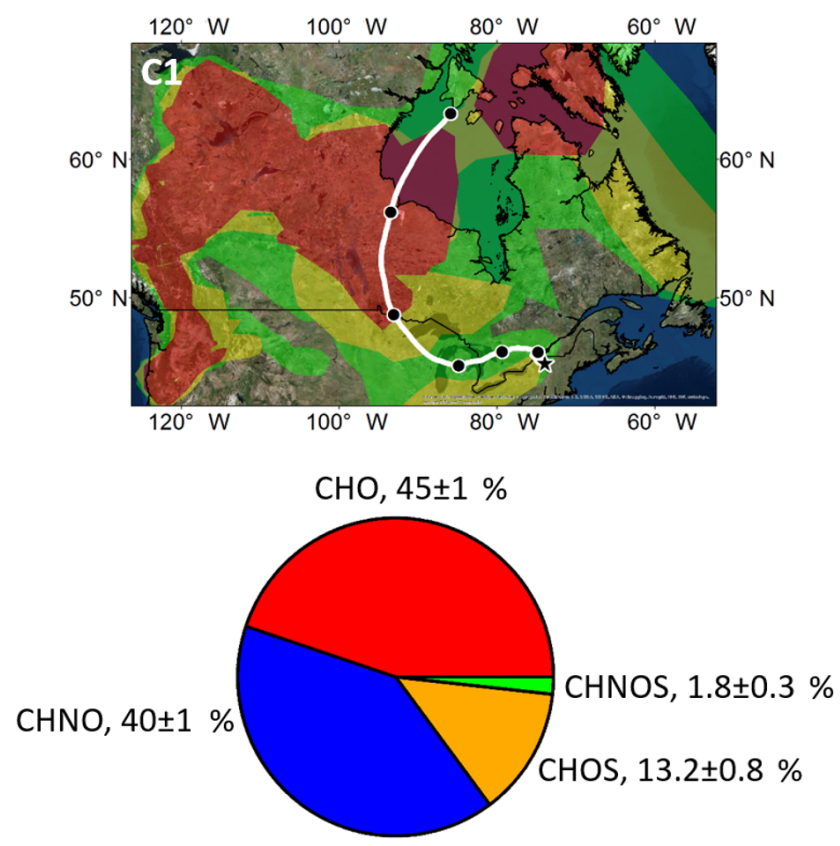

Figure 4. NOAA HYSPLIT $144 \mathrm{~h}$ (6-day) backward air mass trajectory (white line, with 1-day resolution, shown as black dots) and corresponding cloud water molecular composition, shown as compound-type number fractions during the wildfire event (sample C1). Green, yellow, and red shading on the map represents low, moderate, and high amounts of smoke, respectively, as defined by the NOAA Hazard Mapping System Fire and Smoke Product (http://www.ospo.noaa.gov/Products/land/hms.html).

sample (Table 2), consistent with the urban air mass influence. In a recent study by Boone et al. (2015) in the southeastern US, several of these aliphatic organosulfates were observed in below-cloud atmospheric particles but not in the cloud water. Similar to the northern biogenic-influenced cloud water, many likely monoterpene-derived organosulfates and nitrooxy-organosulfates (Nguyen et al., 2012b; Surratt et al., 2008), as well as corresponding hydrolysis products (or precursors), were observed in the B1 and B2 cloud water samples (Tables 2 and 3), due to the time the air mass spent over the forested areas of the southeast and midwest US (Fig. S1).

\subsection{Canadian wildfire influence}

Backward air mass trajectories combined with NOAA Hazard Mapping System and Smoke Product data indicate influence from Canadian wildfire smoke during 4-6 August 2014 at Whiteface Mountain (Figs. 4 and S5). Cloud water $\mathrm{pH}$ ranged from 4.05 to 4.54 , generally lower than the biogenic- and urban-influenced samples and the AugustSeptember 2014 average of $4.8 \pm 0.1$. The cloud water inorganic ion concentrations were the highest observed in this study, although sample C3 had lower inorganic ion concentrations than the $\mathrm{C} 1$ and $\mathrm{C} 2$ samples (Table 1). Elevated $\mathrm{K}^{+}$ 
Table 3. Identified aqueous SOA tracers $(\mathrm{m} / \mathrm{z}$, molecular formula, suggested VOC precursor, and compound type, based on bulk aqueous laboratory studies) in each cloud water sample.

\begin{tabular}{|c|c|c|c|c|}
\hline $\begin{array}{l}{[\mathrm{M}-\mathrm{H}]^{-}} \\
(m / z)\end{array}$ & $\begin{array}{l}\text { Molecular } \\
\text { formula }\end{array}$ & $\begin{array}{l}\text { VOC } \\
\text { precursors }\end{array}$ & Compound type & Observed in cloud water samples \\
\hline 213.0769 & $\mathrm{C}_{10} \mathrm{H}_{14} \mathrm{O}_{5}$ & & Aqueous monoterpene & $\mathrm{A} 1, \mathrm{~A} 2, \mathrm{~A} 3, \mathrm{~B} 1, \mathrm{~B} 2, \mathrm{C} 1, \mathrm{C} 2, \mathrm{C} 3$ \\
\hline 229.0718 & $\mathrm{C}_{10} \mathrm{H}_{14} \mathrm{O}_{6}$ & $\alpha$-pinene & $\begin{array}{l}\text { SOA tracers (Aljawhary } \\
\text { et al., 2016) }\end{array}$ & $\mathrm{A} 1, \mathrm{~A} 2, \mathrm{~A} 3, \mathrm{~B} 1, \mathrm{~B} 2, \mathrm{C} 1, \mathrm{C} 2, \mathrm{C} 3$ \\
\hline 157.0506 & $\mathrm{C}_{7} \mathrm{H}_{10} \mathrm{O}_{4}$ & \multirow{3}{*}{ Methyl vinyl ketone } & \multirow{3}{*}{$\begin{array}{l}\text { Aqueous isoprene SOA } \\
\text { tracers (Renard et } \\
\text { al., 2015) }\end{array}$} & $\mathrm{B} 1, \mathrm{C} 1, \mathrm{C} 2, \mathrm{C} 3$ \\
\hline 159.0663 & $\mathrm{C}_{7} \mathrm{H}_{12} \mathrm{O}_{4}$ & & & $\mathrm{~B} 1, \mathrm{C} 3$ \\
\hline 199.0612 & $\mathrm{C}_{9} \mathrm{H}_{12} \mathrm{O}_{5}$ & & & $\mathrm{~A} 2, \mathrm{~A} 3, \mathrm{~B} 1, \mathrm{~B} 2, \mathrm{C} 1, \mathrm{C} 2, \mathrm{C} 3$ \\
\hline 320.7606 & $\mathrm{C}_{13} \mathrm{H}_{22} \mathrm{O}_{9}$ & \multirow{9}{*}{ Isoprene } & \multirow{9}{*}{$\begin{array}{l}\text { Aqueous isoprene SOA } \\
\text { tracers (Nguyen et } \\
\text { al., 2012a) }\end{array}$} & $\mathrm{A} 2, \mathrm{~B} 1, \mathrm{C} 1, \mathrm{C} 2, \mathrm{C} 3$ \\
\hline 318.7835 & $\mathrm{C}_{14} \mathrm{H}_{24} \mathrm{O}_{8}$ & & & $\mathrm{~A} 1, \mathrm{~A} 2, \mathrm{~A} 3, \mathrm{~B} 1, \mathrm{~B} 2, \mathrm{C} 1, \mathrm{C} 2, \mathrm{C} 3$ \\
\hline 330.7337 & $\mathrm{C}_{14} \mathrm{H}_{20} \mathrm{O}_{9}$ & & & $\mathrm{~A} 1, \mathrm{~A} 3, \mathrm{~B} 1, \mathrm{~B} 2, \mathrm{C} 1, \mathrm{C} 2, \mathrm{C} 3$ \\
\hline 348.7242 & $\mathrm{C}_{14} \mathrm{H}_{22} \mathrm{O}_{10}$ & & & $\mathrm{~A} 3, \mathrm{~B} 1, \mathrm{C} 1, \mathrm{C} 2, \mathrm{C} 3$ \\
\hline 364.7012 & $\mathrm{C}_{14} \mathrm{H}_{22} \mathrm{O}_{11}$ & & & $\mathrm{C} 1, \mathrm{C} 2$ \\
\hline 346.7471 & $\mathrm{C}_{15} \mathrm{H}_{24} \mathrm{O}_{9}$ & & & $\mathrm{~A} 1, \mathrm{~A} 2, \mathrm{~A} 3, \mathrm{~B} 1, \mathrm{~B} 2, \mathrm{C} 1, \mathrm{C} 2, \mathrm{C} 3$ \\
\hline 392.6649 & $\mathrm{C}_{15} \mathrm{H}_{22} \mathrm{O}_{12}$ & & & $\mathrm{C} 1, \mathrm{C} 2$ \\
\hline 406.6650 & $\mathrm{C}_{16} \mathrm{H}_{24} \mathrm{O}_{12}$ & & & $\mathrm{C} 1, \mathrm{C} 2, \mathrm{C} 3$ \\
\hline 436.6420 & $\mathrm{C}_{17} \mathrm{H}_{26} \mathrm{O}_{13}$ & & & $\mathrm{C} 1, \mathrm{C} 2$ \\
\hline 185.0455 & $\mathrm{C}_{8} \mathrm{H}_{10} \mathrm{O}_{5}$ & \multirow{8}{*}{$\begin{array}{l}\text { Syringol }(2,6- \\
\text { dimethoxyphenol) }\end{array}$} & \multirow{12}{*}{$\begin{array}{l}\text { Aqueous biomass burning } \\
\text { SOA tracers (Yu et } \\
\text { al., 2014, 2016) }\end{array}$} & $\mathrm{B} 1, \mathrm{C} 1, \mathrm{C} 2, \mathrm{C} 3$ \\
\hline 251.0562 & $\mathrm{C}_{12} \mathrm{H}_{12} \mathrm{O}_{6}$ & & & $\mathrm{~B} 1, \mathrm{C} 1, \mathrm{C} 2, \mathrm{C} 3$ \\
\hline 267.0511 & $\mathrm{C}_{12} \mathrm{H}_{12} \mathrm{O}_{7}$ & & & $\mathrm{~B} 1, \mathrm{C} 2, \mathrm{C} 3$ \\
\hline 289.0718 & $\mathrm{C}_{15} \mathrm{H}_{14} \mathrm{O}_{6}$ & & & $\mathrm{~B} 1, \mathrm{C} 1, \mathrm{C} 2, \mathrm{C} 3$ \\
\hline 291.0874 & $\mathrm{C}_{15} \mathrm{H}_{16} \mathrm{O}_{6}$ & & & $\mathrm{~B} 1, \mathrm{~B} 2, \mathrm{C} 1, \mathrm{C} 2, \mathrm{C} 3$ \\
\hline 309.0980 & $\mathrm{C}_{15} \mathrm{H}_{18} \mathrm{O}_{7}$ & & & $\mathrm{~A} 1, \mathrm{~A} 2, \mathrm{~A} 3, \mathrm{~B} 1, \mathrm{~B} 2, \mathrm{C} 1, \mathrm{C} 2, \mathrm{C} 3$ \\
\hline 339.0722 & $\mathrm{C}_{15} \mathrm{H}_{16} \mathrm{O}_{9}$ & & & $\mathrm{~B} 1, \mathrm{C} 1, \mathrm{C} 2, \mathrm{C} 3$ \\
\hline 305.1030 & $\mathrm{C}_{16} \mathrm{H}_{18} \mathrm{O}_{6}$ & & & $\mathrm{~A} 2, \mathrm{~B} 1, \mathrm{~B} 2, \mathrm{C} 1, \mathrm{C} 2, \mathrm{C} 3$ \\
\hline 262.7625 & $\mathrm{C}_{13} \mathrm{H}_{12} \mathrm{O}_{6}$ & \multirow{4}{*}{$\begin{array}{l}\text { Guaiacol } \\
\text { (2-methoxyphenol) }\end{array}$} & & $\mathrm{B} 1, \mathrm{C} 1, \mathrm{C} 2, \mathrm{C} 3$ \\
\hline 260.7854 & $\mathrm{C}_{14} \mathrm{H}_{14} \mathrm{O}_{5}$ & & & $\mathrm{~B} 1, \mathrm{C} 1, \mathrm{C} 2, \mathrm{C} 3$ \\
\hline 274.7490 & $\mathrm{C}_{14} \mathrm{H}_{12} \mathrm{O}_{6}$ & & & $\mathrm{~B} 1, \mathrm{C} 3$ \\
\hline 276.7624 & $\mathrm{C}_{14} \mathrm{H}_{14} \mathrm{O}_{6}$ & & & $\mathrm{~A} 2, \mathrm{~B} 1, \mathrm{~B} 2, \mathrm{C} 1, \mathrm{C} 2, \mathrm{C} 3$ \\
\hline
\end{tabular}

concentrations, commonly used as a tracer of biomass burning (Artaxo et al., 1994), were present in the wildfire samples $(1.30-5.38 \mu \mathrm{M})$, compared to the non-wildfire conditions (biogenic and urban samples: $0.02-0.87 \mu \mathrm{M}$ ) (Table 1). A positive correlation between $\mathrm{K}^{+}$and TOC concentrations was observed (Fig. S6), with increased TOC mass concentrations $\left(7.86-16.6 \mathrm{mg} \mathrm{L}^{-1}\right)$ in wildfire-influenced cloud water, compared to non-wildfire conditions $\left(0.73-2.16 \mathrm{mg} \mathrm{L}^{-1}\right)$, as well as the August-September 2010-2015 averages (Table S1). While the contribution of aqueous SOA formation to the measured TOC cannot be determined in this study, Gilardoni et al. (2016) reported production of light-absorbing SOA and an increase in $\mathrm{O}: \mathrm{C}$ ratio from aqueous-phase processing of biomass burning emissions. Notably, there appears to be a greater diversity of oligomeric compounds present in the wildfire samples (Figs. 2 and S2), which is likely a combination of the identities of the specific organic compounds present at high concentrations in the smoke, as well as the potential role of acidity (as observed through cloud water acidity), resulting in the production of the observed oligomeric species, likely in aqueous aerosol prior to cloud droplet activation (Ervens et al., 2011).

Previously, Nguyen et al. (2012b) observed the formation of organosulfates following evaporation and re-dissolution of an aqueous solution ( $\mathrm{pH} 2-4)$ of sulfuric acid mixed with SOA formed from $d$-limonene ozonolysis. In this study, numerous possible organosulfates corresponding to the formulas observed by Nguyen et al. (2012b) were identified in urban- and wildfire-influenced cloud water samples but not in the biogenic samples (Table 4). Notably, unlike the common organosulfates, likely formed through reactive uptake of epoxides on aqueous aerosol (Surratt et al., 2010) and listed in Table 2, these organosulfates were primarily observed in the $\mathrm{B} 1, \mathrm{C} 1$, and $\mathrm{C} 2$ samples, which were characterized by the highest sulfate cloud water concentrations $(30.7,69.4$, and $103.2 \mu \mathrm{M}$, respectively) and lowest $\mathrm{pH}(4.05-4.18)$, compared to the other cloud water samples $\left(\mathrm{SO}_{4}^{2-} \leq 10.1 \mu \mathrm{M}\right.$, $\mathrm{pH}>4.5$ ) (Table 1). Since these organosulfates were observed in cloud water, the compounds are likely relatively stable toward hydrolysis. However, possible hydrolysis prod- 
Table 4. Identity of possible organosulfates, previously observed in the laboratory from the evaporation and re-dissolution of an aqueous solution of $d$-limonene SOA and sulfuric acid (Nguyen et al., 2012 b), in each cloud water sample, with observed potential hydrolysis products noted.

\begin{tabular}{|c|c|c|c|}
\hline $\begin{array}{l}{[\mathrm{M}-\mathrm{H}]^{-}} \\
(m / z)\end{array}$ & $\begin{array}{l}\text { Molecular } \\
\text { formula }\end{array}$ & $\begin{array}{l}\text { Observed in } \\
\text { cloud water } \\
\text { samples }\end{array}$ & $\begin{array}{l}\text { Observed } \\
\text { potential } \\
\text { hydrolysis } \\
\text { products }\end{array}$ \\
\hline 223.0280 & $\mathrm{C}_{7} \mathrm{H}_{12} \mathrm{O}_{6} \mathrm{~S}$ & $\mathrm{~B} 1, \mathrm{C} 1, \mathrm{C} 2$ & $\mathrm{C}_{7} \mathrm{H}_{12} \mathrm{O}_{3}$ \\
\hline 225.0437 & $\mathrm{C}_{7} \mathrm{H}_{14} \mathrm{O}_{6} \mathrm{~S}$ & $\mathrm{~B} 1, \mathrm{C} 1, \mathrm{C} 2$ & - \\
\hline 239.0229 & $\mathrm{C}_{7} \mathrm{H}_{12} \mathrm{O}_{7} \mathrm{~S}$ & $\mathrm{~B} 1, \mathrm{C} 1$ & $\mathrm{C}_{7} \mathrm{H}_{12} \mathrm{O}_{4}$ \\
\hline 235.0280 & $\mathrm{C}_{8} \mathrm{H}_{12} \mathrm{O}_{6} \mathrm{~S}$ & $\mathrm{~B} 1, \mathrm{C} 1$ & - \\
\hline 237.0436 & $\mathrm{C}_{8} \mathrm{H}_{14} \mathrm{O}_{6} \mathrm{~S}$ & $\mathrm{~B} 1, \mathrm{C} 1, \mathrm{C} 2, \mathrm{C} 3$ & - \\
\hline 251.0229 & $\mathrm{C}_{8} \mathrm{H}_{12} \mathrm{O}_{7} \mathrm{~S}$ & $\mathrm{~B} 1, \mathrm{C} 1, \mathrm{C} 2$ & - \\
\hline 253.0386 & $\mathrm{C}_{8} \mathrm{H}_{14} \mathrm{O}_{7} \mathrm{~S}$ & $\mathrm{~B} 1, \mathrm{C} 1, \mathrm{C} 2$ & - \\
\hline 267.0179 & $\mathrm{C}_{8} \mathrm{H}_{12} \mathrm{O}_{8} \mathrm{~S}$ & $\mathrm{~B} 1, \mathrm{C} 1, \mathrm{C} 2$ & $\mathrm{C}_{8} \mathrm{H}_{12} \mathrm{O}_{5}$ \\
\hline 249.0438 & $\mathrm{C}_{9} \mathrm{H}_{14} \mathrm{O}_{6} \mathrm{~S}$ & $\mathrm{~B} 1, \mathrm{C} 1, \mathrm{C} 2, \mathrm{C} 3$ & - \\
\hline 251.0594 & $\mathrm{C}_{9} \mathrm{H}_{16} \mathrm{O}_{6} \mathrm{~S}$ & $\mathrm{~B} 1, \mathrm{C} 1, \mathrm{C} 2, \mathrm{C} 3$ & - \\
\hline 263.0231 & $\mathrm{C}_{9} \mathrm{H}_{12} \mathrm{O}_{7} \mathrm{~S}$ & $\mathrm{~B} 1$ & - \\
\hline 265.0387 & $\mathrm{C}_{9} \mathrm{H}_{14} \mathrm{O}_{7} \mathrm{~S}$ & $\mathrm{~B} 1, \mathrm{~B} 2, \mathrm{C} 1, \mathrm{C} 2, \mathrm{C} 3$ & - \\
\hline 267.0543 & $\mathrm{C}_{9} \mathrm{H}_{16} \mathrm{O}_{7} \mathrm{~S}$ & $\mathrm{~B} 1, \mathrm{C} 1, \mathrm{C} 2, \mathrm{C} 3$ & - \\
\hline 281.0335 & $\mathrm{C}_{9} \mathrm{H}_{14} \mathrm{O}_{8} \mathrm{~S}$ & $\mathrm{~B} 1, \mathrm{C} 1, \mathrm{C} 2, \mathrm{C} 3$ & $\mathrm{C}_{9} \mathrm{H}_{14} \mathrm{O}_{5}$ \\
\hline 297.0285 & $\mathrm{C}_{9} \mathrm{H}_{14} \mathrm{O}_{9} \mathrm{~S}$ & $\mathrm{~B} 1, \mathrm{C} 1, \mathrm{C} 2$ & $\mathrm{C}_{9} \mathrm{H}_{14} \mathrm{O}_{6}$ \\
\hline 299.0441 & $\mathrm{C}_{9} \mathrm{H}_{16} \mathrm{O}_{9} \mathrm{~S}$ & $\mathrm{C} 1$ & $\mathrm{C}_{9} \mathrm{H}_{16} \mathrm{O}_{6}$ \\
\hline 263.0593 & $\mathrm{C}_{10} \mathrm{H}_{16} \mathrm{O}_{6} \mathrm{~S}$ & $\mathrm{~B} 1, \mathrm{~B} 2, \mathrm{C} 1, \mathrm{C} 2, \mathrm{C} 3$ & - \\
\hline 277.0387 & $\mathrm{C}_{10} \mathrm{H}_{14} \mathrm{O}_{7} \mathrm{~S}$ & $\mathrm{~B} 1, \mathrm{C} 1, \mathrm{C} 2, \mathrm{C} 3$ & - \\
\hline 279.0542 & $\mathrm{C}_{10} \mathrm{H}_{16} \mathrm{O}_{7} \mathrm{~S}$ & $\mathrm{~B} 1, \mathrm{~B} 2, \mathrm{C} 1, \mathrm{C} 2, \mathrm{C} 3$ & $\mathrm{C}_{10} \mathrm{H}_{16} \mathrm{O}_{4}$ \\
\hline 281.0698 & $\mathrm{C}_{10} \mathrm{H}_{18} \mathrm{O}_{7} \mathrm{~S}$ & $\mathrm{~B} 1, \mathrm{~B} 2, \mathrm{C} 1, \mathrm{C} 2, \mathrm{C} 3$ & $\mathrm{C}_{10} \mathrm{H}_{18} \mathrm{O}_{4}$ \\
\hline 293.0337 & $\mathrm{C}_{10} \mathrm{H}_{14} \mathrm{O}_{8} \mathrm{~S}$ & $\mathrm{~B} 1, \mathrm{C} 1, \mathrm{C} 2$ & $\mathrm{C}_{10} \mathrm{H}_{14} \mathrm{O}_{5}$ \\
\hline 295.0493 & $\mathrm{C}_{10} \mathrm{H}_{16} \mathrm{O}_{8} \mathrm{~S}$ & $\mathrm{~B} 1, \mathrm{~B} 2, \mathrm{C} 1, \mathrm{C} 2, \mathrm{C} 3$ & $\mathrm{C}_{10} \mathrm{H}_{16} \mathrm{O}_{5}$ \\
\hline 297.0648 & $\mathrm{C}_{10} \mathrm{H}_{18} \mathrm{O}_{8} \mathrm{~S}$ & $\mathrm{~B} 1, \mathrm{~B} 2, \mathrm{C} 1, \mathrm{C} 2, \mathrm{C} 3$ & $\mathrm{C}_{10} \mathrm{H}_{18} \mathrm{O}_{5}$ \\
\hline 311.0441 & $\mathrm{C}_{10} \mathrm{H}_{16} \mathrm{O}_{9} \mathrm{~S}$ & $\mathrm{~B} 1, \mathrm{C} 1, \mathrm{C} 2, \mathrm{C} 3$ & $\mathrm{C}_{10} \mathrm{H}_{16} \mathrm{O}_{6}$ \\
\hline 327.0388 & $\mathrm{C}_{10} \mathrm{H}_{16} \mathrm{O}_{10} \mathrm{~S}$ & $\mathrm{~B} 1, \mathrm{C} 1, \mathrm{C} 2$ & $\mathrm{C}_{10} \mathrm{H}_{16} \mathrm{O}_{7}$ \\
\hline 329.0546 & $\mathrm{C}_{10} \mathrm{H}_{18} \mathrm{O}_{10} \mathrm{~S}$ & $\mathrm{C} 1$ & $\mathrm{C}_{10} \mathrm{H}_{18} \mathrm{O}_{7}$ \\
\hline 423.0961 & $\mathrm{C}_{16} \mathrm{H}_{24} \mathrm{O}_{11} \mathrm{~S}$ & $\mathrm{~B} 1, \mathrm{C} 1, \mathrm{C} 2$ & $\mathrm{C}_{16} \mathrm{H}_{24} \mathrm{O}_{8}$ \\
\hline 441.1072 & $\mathrm{C}_{16} \mathrm{H}_{26} \mathrm{O}_{12} \mathrm{~S}$ & $\mathrm{~B} 1, \mathrm{C} 1, \mathrm{C} 2$ & $\mathrm{C}_{16} \mathrm{H}_{26} \mathrm{O}_{9}$ \\
\hline 457.1030 & $\mathrm{C}_{16} \mathrm{H}_{26} \mathrm{O}_{13} \mathrm{~S}$ & $\mathrm{~B} 1, \mathrm{C} 1, \mathrm{C} 2$ & $\mathrm{C}_{16} \mathrm{H}_{26} \mathrm{O}_{10}$ \\
\hline 439.1279 & $\mathrm{C}_{17} \mathrm{H}_{28} \mathrm{O}_{11} \mathrm{~S}$ & $\mathrm{~B} 1, \mathrm{C} 1, \mathrm{C} 2, \mathrm{C} 3$ & $\mathrm{C}_{17} \mathrm{H}_{28} \mathrm{O}_{8}$ \\
\hline 455.1234 & $\mathrm{C}_{17} \mathrm{H}_{28} \mathrm{O}_{12} \mathrm{~S}$ & $\mathrm{~B} 1, \mathrm{C} 1, \mathrm{C} 2, \mathrm{C} 3$ & $\mathrm{C}_{17} \mathrm{H}_{28} \mathrm{O}_{9}$ \\
\hline 469.1028 & $\mathrm{C}_{17} \mathrm{H}_{26} \mathrm{O}_{13} \mathrm{~S}$ & $\mathrm{C} 1, \mathrm{C} 2$ & - \\
\hline 471.1177 & $\mathrm{C}_{17} \mathrm{H}_{28} \mathrm{O}_{13} \mathrm{~S}$ & $\mathrm{C} 1, \mathrm{C} 2$ & $\mathrm{C}_{17} \mathrm{H}_{28} \mathrm{O}_{10}$ \\
\hline 451.1275 & $\mathrm{C}_{18} \mathrm{H}_{28} \mathrm{O}_{11} \mathrm{~S}$ & $\mathrm{~B} 1, \mathrm{~B} 2, \mathrm{C} 1, \mathrm{C} 2, \mathrm{C} 3$ & $\mathrm{C}_{18} \mathrm{H}_{28} \mathrm{O}_{8}$ \\
\hline 465.1075 & $\mathrm{C}_{18} \mathrm{H}_{26} \mathrm{O}_{12} \mathrm{~S}$ & $\mathrm{C} 1, \mathrm{C} 2$ & - \\
\hline 467.1230 & $\mathrm{C}_{18} \mathrm{H}_{28} \mathrm{O}_{12} \mathrm{~S}$ & $\mathrm{C} 1, \mathrm{C} 2$ & $\mathrm{C}_{18} \mathrm{H}_{28} \mathrm{O}_{9}$ \\
\hline 469.1385 & $\mathrm{C}_{18} \mathrm{H}_{30} \mathrm{O}_{12} \mathrm{~S}$ & $\mathrm{~B} 1, \mathrm{C} 1, \mathrm{C} 2$ & $\mathrm{C}_{18} \mathrm{H}_{30} \mathrm{O}_{9}$ \\
\hline 483.1180 & $\mathrm{C}_{18} \mathrm{H}_{28} \mathrm{O}_{13} \mathrm{~S}$ & $\mathrm{~B} 1, \mathrm{C} 1, \mathrm{C} 2$ & - \\
\hline 485.1330 & $\mathrm{C}_{18} \mathrm{H}_{30} \mathrm{O}_{13} \mathrm{~S}$ & $\mathrm{~B} 1, \mathrm{C} 1, \mathrm{C} 2$ & $\mathrm{C}_{18} \mathrm{H}_{30} \mathrm{O}_{10}$ \\
\hline 499.1127 & $\mathrm{C}_{18} \mathrm{H}_{28} \mathrm{O}_{14} \mathrm{~S}$ & $\mathrm{C} 1$ & - \\
\hline 481.1385 & $\mathrm{C}_{19} \mathrm{H}_{30} \mathrm{O}_{12} \mathrm{~S}$ & $\mathrm{~B} 1, \mathrm{C} 1, \mathrm{C} 2, \mathrm{C} 3$ & $\mathrm{C}_{19} \mathrm{H}_{30} \mathrm{O}_{9}$ \\
\hline 483.1537 & $\mathrm{C}_{19} \mathrm{H}_{32} \mathrm{O}_{12} \mathrm{~S}$ & $\mathrm{~B} 1, \mathrm{C} 1, \mathrm{C} 2, \mathrm{C} 3$ & $\mathrm{C}_{19} \mathrm{H}_{32} \mathrm{O}_{9}$ \\
\hline 497.1341 & $\mathrm{C}_{19} \mathrm{H}_{30} \mathrm{O}_{13} \mathrm{~S}$ & $\mathrm{C} 1$ & - \\
\hline 513.1276 & $\mathrm{C}_{19} \mathrm{H}_{30} \mathrm{O}_{14} \mathrm{~S}$ & $\mathrm{C} 1, \mathrm{C} 2$ & - \\
\hline 513.1653 & $\mathrm{C}_{20} \mathrm{H}_{34} \mathrm{O}_{13} \mathrm{~S}$ & $\mathrm{~B} 1, \mathrm{C} 3$ & $\mathrm{C}_{20} \mathrm{H}_{34} \mathrm{O}_{10}$ \\
\hline
\end{tabular}

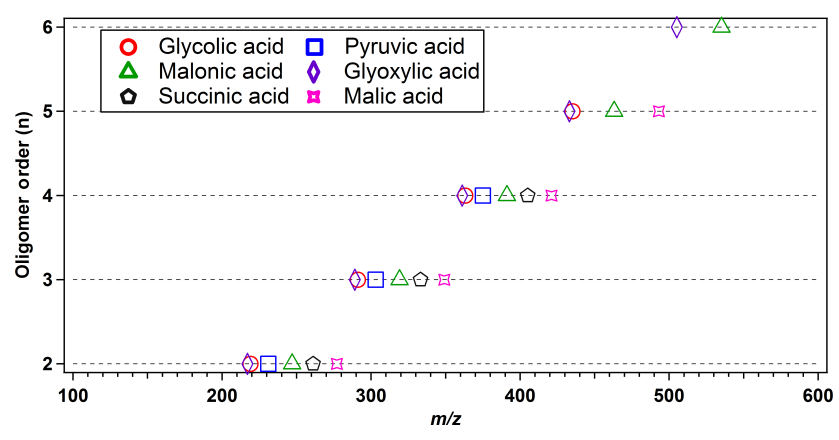

Figure 5. Order of oligomer $(n)$ corresponding to the number of methylglyoxal $\left(\mathrm{C}_{3} \mathrm{H}_{4} \mathrm{O}_{2}\right)$ additions $(\Delta m / z=72.02113)$ to specific parent organic acids (listed in the legend), proposed to form through aqueous processing and measured in cloud water during the wildfire-influenced period $(\mathrm{C} 1-\mathrm{C} 3)$. Compound identification was based on comparison of elemental formulas calculated from (-) ESI-FTICR-MS data with the oligomeric series previously reported by Altieri et al. (2008) from the aqueous reactions of methylglyoxal and $\mathrm{OH}$.

ucts of many of the organosulfates were also observed (Table 4). Overall, these observations are consistent with suggested acid-catalyzed organosulfate formation via the formation of aldol condensation products, followed by reaction with sulfuric acid, during cloud droplet evaporation (Nguyen et al., 2012b).

Biomass burning is one of the largest sources of methylglyoxal (Fu et al., 2008), and aqueous-phase reactive uptake of methylglyoxal has been suggested to be a significant source of organic aerosol (Fu et al., 2009; Zhao et al., 2006) through the formation of carboxylic acids, organosulfates, and oligomers (Altieri et al., 2008; Ervens et al., 2011). During wildfire influence, oligomeric species were observed in cloud water samples, with the addition of up to six $\mathrm{C}_{3} \mathrm{H}_{4} \mathrm{O}_{2}$ (methylglyoxal) monomers to glycolic acid, pyruvic acid, malonic acid, malic acid, glyoxylic acid, and succinic acid (Fig. 5). The masses corresponding to these oligomeric series were also observed by Altieri et al. (2008) in bulk aqueousphase laboratory studies of the photooxidation of methylglyoxal, suggesting the importance of methylglyoxal-hydroxyl radical reactions for oligomer formation. Notably, pyruvic acid is one of the most abundant photooxidation products of methylglyoxal (Altieri et al., 2006; Lim et al., 2013). Modeling suggests that methylglyoxal oligomerization primarily occurs in aqueous aerosols, rather than during cloud processing (Lim et al., 2013; Tan et al., 2010). Aqueousphase methylglyoxal reaction products are expected to remain largely in the aerosol phase upon cloud droplet evaporation (Heaton et al., 2009; Loeffler et al., 2006). Syringol (2,6dimethoxyphenol) and guaiacol (2-methoxyphenol) are also emitted in significant quantities from biomass burning, and previous studies have examined the bulk aqueous-phase photooxidation of syringol and guaiacol (Yu et al., 2014, 2016), showing production of several $\mathrm{CHO}$ compounds that were 
also observed in the wildfire-influenced cloud water studied here (Table 3). Notably, aqueous SOA formation from phenolic compounds has been shown to enhance light absorption in the UV-visible region (Yu et al., 2014), suggesting that these brown carbon compounds in the cloud water may be important upon cloud droplet evaporation.

\section{Conclusions and atmospheric implications}

This study represents only the second determination of high molecular weight organic molecular composition in cloud water at Whiteface Mountain, NY (Sagona et al., 2014), and the first using ultra-high-resolution mass spectrometry. The average $\mathrm{O}: \mathrm{C}$ ratios of the oxygenated high mass organic compounds (negative ion mode, $m / z$ 100-1000) increased with decreasing cloud water $\mathrm{pH}$, suggesting the possibility for aqueous acid-catalyzed (prior to cloud droplet activation or during/after cloud droplet evaporation) and/or radical (within cloud droplet) oxidation reactions contributing to the dissolved organic compounds. However, without knowledge of the organic aerosol composition prior to cloud formation, it is not possible to distinguish between aqueous aerosol and cloud droplet processes in this study. Cloud water samples from different air masses featured notable differences in the detected compounds. A higher absolute number and number fraction of CHNO compounds were observed during the wildfire and urban air mass periods, compared to biogenic influence, likely due to greater $\mathrm{NO}_{x}$ influence. In addition, observations of likely dinitroaromatics during all air mass influences, potentially from aqueous nitration of nitroaromatic compounds, have important implications because of their light-absorbing and mutagenic properties (Purohit and Basu, 2000; Zhang et al., 2011, 2013). During wildfire influence, the cloud water showed evidence of aqueous SOA formation, including oligomer formation involving methylglyoxal (Altieri et al., 2008; Yasmeen et al., 2010) and aqueousphase reactions of syringol and guaiacol (Yu et al., 2014, 2016). Monoterpene-derived organosulfates and organonitrates (Surratt et al., 2008) were observed in the cloud water during all air mass influences, similar to previous cloud water studies (Boone et al., 2015; Pratt et al., 2013). Notably, long-chain, alkane-derived organosulfates (Riva et al., 2016) were observed in cloud water when urban influence was present. Future work comparing cloud water composition with aqueous aerosol is needed to isolate in-cloud processes from aqueous-aerosol processes.

Data availability. The complete list of identified mass spectral ion peaks, with assignments and intensities noted for each cloud water sample, is provided in Table S3.

\section{The Supplement related to this article is available online at https://doi.org/10.5194/acp-17-15167-2017- supplement.}

Competing interests. The authors declare that they have no conflict of interest.

Acknowledgements. This study was supported by the New York State Energy Research and Development Authority (NYSERDA, contract no. 53968) and a University of Michigan (U-M) College of Literature, Science, and the Arts Honors grant to Zhuoyu Peng. Ryan D. Cook was supported by a U-M Rackham Graduate School Merit Fellowship. Ying-Hsuan Lin was supported by a postdoctoral fellowship from the U-M College of the Literature, Science, and the Arts and the Michigan Society of Fellows. Zhuoyu Peng was supported by a U-M Department of Chemistry Summer Undergraduate Research Program Fellowship. High-resolution mass spectrometry analyses were performed at the Environmental Molecular Sciences Laboratory (EMSL), a national scientific user facility located at the Pacific Northwest National Laboratory (PNNL) and sponsored by the Office of Biological and Environmental Research of the US Department of Energy (DOE). PNNL is operated for DOE by Battelle Memorial Institute under contract no. DE-AC0676RL0 1830. ALSC (Adirondack Lake Survey Corporation) cloud water collection is supported by the New York State Department of Environmental Conservation and NYSERDA. The authors thank Lynn Mazzoleni (Michigan Technological University) for discussion about the solid-phase extraction methodology, as well as Stephen McNamara (U-M) for research assistance. The authors gratefully acknowledge the NOAA Air Resources Laboratory for the provision of the HYSPLIT transport and dispersion model used in this work.

Edited by: Thomas Karl

Reviewed by: two anonymous referees

\section{References}

Aleksic, N. and Dukett, J. E.: Probabilistic relationship between liquid water content and ion concentrations in cloud water, Atmos. Res., 98, 400-405, https://doi.org/10.1016/j.atmosres.2010.08.003, 2010.

Aleksic, N., Roy, K., Sistla, G., Dukett, J., Houck, N., and Casson, P.: Analysis of cloud and precipitation chemistry at Whiteface Mountain, NY, Atmos. Environ., 43, 2709-2716, https://doi.org/10.1016/j.atmosenv.2009.02.053, 2009.

Aljawhary, D., Zhao, R., Lee, A. K. Y., Wang, C., and Abbatt, J. P. D.: Kinetics, Mechanism, and Secondary Organic Aerosol Yield of Aqueous Phase Photo-oxidation of $\alpha$-Pinene Oxidation Products, J. Phys. Chem. A, 120, 1395-1407, https://doi.org/10.1021/acs.jpca.5b06237, 2016.

Altieri, K. E., Carlton, A. G., Lim, H.-J., Turpin, B. J., and Seitzinger, S. P.: Evidence for Oligomer Formation in Clouds: Reactions of Isoprene Oxidation Products, Environ. Sci. Technol., 40, 4956-4960, https://doi.org/10.1021/es052170n, 2006. 
Altieri, K. E., Seitzinger, S. P., Carlton, A. G., Turpin, B. J., Klein, G. C., and Marshall, A. G.: Oligomers formed through in-cloud methylglyoxal reactions: Chemical composition, properties, and mechanisms investigated by ultra-high resolution FT-ICR mass spectrometry, Atmos. Environ., 42, 1476-1490, https://doi.org/10.1016/j.atmosenv.2007.11.015, 2008.

Artaxo, P., Gerab, F., Yamasoe, M. A., and Martins, J. V.: Fine mode aerosol composition at three long-term atmospheric monitoring sites in the Amazon Basin, J. Geophys. Res.-Atmos., 99, 22857 22868, https://doi.org/10.1029/94JD01023, 1994.

Baumgardner, R. E., Isil, S. S., Lavery, T. F., Rogers, C. M., and Mohnen, V. A.: Estimates of Cloud Water Deposition at Mountain Acid Deposition Program Sites in the Appalachian Mountains, J. Air Waste Manage. Assoc., 53, 291-308, https://doi.org/10.1080/10473289.2003.10466153, 2003.

Blando, J. D. and Turpin, B. J.: Secondary organic aerosol formation in cloud and fog droplets: a literature evaluation of plausibility, Atmos. Environ., 34, 1623-1632, https://doi.org/10.1016/S1352-2310(99)00392-1, 2000.

Boone, E. J., Laskin, A., Laskin, J., Wirth, C., Shepson, P. B., Stirm, B. H., and Pratt, K. A.: Aqueous Processing of Atmospheric Organic Particles in Cloud Water Collected via Aircraft Sampling, Environ. Sci. Technol., 49, 8523-8530, https://doi.org/10.1021/acs.est.5b01639, 2015.

Carlton, A. G., Turpin, B. J., Altieri, K. E., Seitzinger, S. P., Mathur, R., Roselle, S. J., and Weber, R. J.: CMAQ Model Performance Enhanced When In-Cloud Secondary Organic Aerosol is Included: Comparisons of Organic Carbon Predictions with Measurements, Environ. Sci. Technol., 42, 87988802, https://doi.org/10.1021/es801192n, 2008.

Chen, Q., Heald, C. L., Jimenez, J. L., Canagaratna, M. R., Zhang, Q., He, L.-Y., Huang, X.-F., Campuzano-Jost, P., Palm, B. B., Poulain, L., Kuwata, M., Martin, S. T., Abbatt, J. P. D., Lee, A. K. Y., and Liggio, J.: Elemental composition of organic aerosol: The gap between ambient and laboratory measurements, Geophys. Res. Lett., 42, 4182-4189, https://doi.org/10.1002/2015GL063693, 2015.

Darer, A. I., Cole-Filipiak, N. C., O'Connor, A. E., and Elrod, M. J.: Formation and Stability of Atmospherically Relevant IsopreneDerived Organosulfates and Organonitrates, Environ. Sci. Technol., 45, 1895-1902, https://doi.org/10.1021/es103797z, 2011.

Dukett, J. E., Aleksic, N., Houck, N., Snyder, P., Casson, P., and Cantwell, M.: Progress toward clean cloud water at Whiteface Mountain New York, Atmos. Environ., 45, 6669-6673, https://doi.org/10.1016/j.atmosenv.2011.08.070, 2011.

Ervens, B., Turpin, B. J., and Weber, R. J.: Secondary organic aerosol formation in cloud droplets and aqueous particles (aqSOA): a review of laboratory, field and model studies, Atmos. Chem. Phys., 11, 11069-11102, https://doi.org/10.5194/acp-1111069-2011, 2011.

Ervens, B., Renard, P., Tlili, S., Ravier, S., Clément, J.-L., and Monod, A.: Aqueous-phase oligomerization of methyl vinyl ketone through photooxidation - Part 2: Development of the chemical mechanism and atmospheric implications, Atmos. Chem. Phys., 15, 9109-9127, https://doi.org/10.5194/acp-159109-2015, 2015.

Feng, J. and Möller, D.: Characterization of Water-Soluble Macromolecular Substances in Cloud Water, J. Atmos. Chem., 48, $217-$
233, https://doi.org/10.1023/B:JOCH.0000044377.93748.e4, 2004.

Fu, T.-M., Jacob, D. J., Wittrock, F., Burrows, J. P., Vrekoussis, M., and Henze, D. K.: Global budgets of atmospheric glyoxal and methylglyoxal, and implications for formation of secondary organic aerosols, J. Geophys. Res.-Atmos., 113, D15303, https://doi.org/10.1029/2007JD009505, 2008

Fu, T.-M., Jacob, D. J., and Heald, C. L.: Aqueous-phase reactive uptake of dicarbonyls as a source of organic aerosol over eastern North America, Atmos. Environ., 43, 1814-1822, https://doi.org/10.1016/j.atmosenv.2008.12.029, 2009.

Gilardoni, S., Massoli, P., Paglione, M., Giulianelli, L., Carbone, C., Rinaldi, M., Decesari, S., Sandrini, S., Costabile, F., Gobbi, G. P., Pietrogrande, M. C., Visentin, M., Scotto, F., Fuzzi, S., and Facchini, M. C.: Direct observation of aqueous secondary organic aerosol from biomassburning emissions, P. Natl. Acad. Sci. USA, 113, 10013-10018, https://doi.org/10.1073/pnas.1602212113, 2016.

Guenther, A., Karl, T., Harley, P., Wiedinmyer, C., Palmer, P. I., and Geron, C.: Estimates of global terrestrial isoprene emissions using MEGAN (Model of Emissions of Gases and Aerosols from Nature), Atmos. Chem. Phys., 6, 3181-3210, https://doi.org/10.5194/acp-6-3181-2006, 2006.

Hallquist, M., Wenger, J. C., Baltensperger, U., Rudich, Y., Simpson, D., Claeys, M., Dommen, J., Donahue, N. M., George, C., Goldstein, A. H., Hamilton, J. F., Herrmann, H., Hoffmann, T., Iinuma, Y., Jang, M., Jenkin, M. E., Jimenez, J. L., Kiendler-Scharr, A., Maenhaut, W., McFiggans, G., Mentel, Th. F., Monod, A., Prévôt, A. S. H., Seinfeld, J. H., Surratt, J. D., Szmigielski, R., and Wildt, J.: The formation, properties and impact of secondary organic aerosol: current and emerging issues, Atmos. Chem. Phys., 9, 5155-5236, https://doi.org/10.5194/acp9-5155-2009, 2009.

Hamilton, J. F., Alfarra, M. R., Robinson, N., Ward, M. W., Lewis, A. C., McFiggans, G. B., Coe, H., and Allan, J. D.: Linking biogenic hydrocarbons to biogenic aerosol in the Borneo rainforest, Atmos. Chem. Phys., 13, 11295-11305, https://doi.org/10.5194/acp-13-11295-2013, 2013.

Heaton, K. J., Sleighter, R. L., Hatcher, P. G., and Wall, W. A.: Composition Domains in Monoterpene Secondary Organic Aerosol, Environ. Sci. Technol., 43, 7797-7802, https://doi.org/10.1021/es901214p, 2009.

Herckes, P., Valsaraj, K. T., and Collett Jr., J. L.: A review of observations of organic matter in fogs and clouds: Origin, processing and fate, Atmos. Res., 132-133, 434-449, https://doi.org/10.1016/j.atmosres.2013.06.005, 2013.

Herrmann, H., Schaefer, T., Tilgner, A., Styler, S. A., Weller, C., Teich, M., and Otto, T.: Tropospheric Aqueous-Phase Chemistry: Kinetics, Mechanisms, and Its Coupling to a Changing Gas Phase, Chem. Rev., 115, 4259-4334, https://doi.org/10.1021/cr500447k, 2015.

Hu, K. S., Darer, A. I., and Elrod, M. J.: Thermodynamics and kinetics of the hydrolysis of atmospherically relevant organonitrates and organosulfates, Atmos. Chem. Phys., 11, 8307-8320, https://doi.org/10.5194/acp-11-8307-2011, 2011

Iinuma, Y., Müller, C., Berndt, T., Böge, O., Claeys, M., and Herrmann, H.: Evidence for the Existence of Organosulfates from $\beta$-Pinene Ozonolysis in Ambient Secondary 
Organic Aerosol, Environ. Sci. Technol., 41, 6678-6683, https://doi.org/10.1021/es070938t, 2007a.

Iinuma, Y., Müller, C., Böge, O., Gnauk, T., and Herrmann, H.: The formation of organic sulfate esters in the limonene ozonolysis secondary organic aerosol (SOA) under acidic conditions, Atmos. Environ., 41, 5571-5583, https://doi.org/10.1016/j.atmosenv.2007.03.007, 2007b.

Iinuma, Y., Boge, O., Kahnt, A., and Herrmann, H.: Laboratory chamber studies on the formation of organosulfates from reactive uptake of monoterpene oxides, Phys. Chem. Chem. Phys., 11, 7985-7997, https://doi.org/10.1039/B904025K, 2009.

Kourtchev, I., Godoi, R. H. M., Connors, S., Levine, J. G., Archibald, A. T., Godoi, A. F. L., Paralovo, S. L., Barbosa, C. G. G., Souza, R. A. F., Manzi, A. O., Seco, R., Sjostedt, S., Park, J.H., Guenther, A., Kim, S., Smith, J., Martin, S. T., and Kalberer, M.: Molecular composition of organic aerosols in central Amazonia: an ultra-high-resolution mass spectrometry study, Atmos. Chem. Phys., 16, 11899-11913, https://doi.org/10.5194/acp-1611899-2016, 2016.

Kristensen, K. and Glasius, M.: Organosulfates and oxidation products from biogenic hydrocarbons in fine aerosols from a forest in North West Europe during spring, Atmos. Environ., 45, 45464556, https://doi.org/10.1016/j.atmosenv.2011.05.063, 2011.

Kristensen, K., Bilde, M., Aalto, P. P., Petäjä, T., and Glasius, M.: Denuder/filter sampling of organic acids and organosulfates at urban and boreal forest sites: Gas/particle distribution and possible sampling artifacts, Atmos. Environ., 130, 36-53, https://doi.org/10.1016/j.atmosenv.2015.10.046, 2016.

Kroflič, A., Grilc, M., and Grgić, I.: Does toxicity of aromatic pollutants increase under remote atmospheric conditions?, Sci. Rep., 5, 8859, https://doi.org/10.1038/srep08859, 2015.

Kujawinski, E. B. and Behn, M. D.: Automated Analysis of Electrospray Ionization Fourier Transform Ion Cyclotron Resonance Mass Spectra of Natural Organic Matter, Anal. Chem., 78, 43634373, https://doi.org/10.1021/ac0600306, 2006.

Laskin, A., Laskin, J., and Nizkorodov, S. A.: Chemistry of Atmospheric Brown Carbon, Chem. Rev., 115, 4335-4382, https://doi.org/10.1021/cr5006167, 2015.

Lee, A. K. Y., Herckes, P., Leaitch, W. R., Macdonald, A. M., and Abbatt, J. P. D.: Aqueous $\mathrm{OH}$ oxidation of ambient organic aerosol and cloud water organics: Formation of highly oxidized products, Geophys. Res. Lett., 38, L11805, https://doi.org/10.1029/2011GL047439, 2011.

Lee, A. K. Y., Hayden, K. L., Herckes, P., Leaitch, W. R., Liggio, J., Macdonald, A. M. and Abbatt, J. P. D.: Characterization of aerosol and cloud water at a mountain site during WACS 2010: secondary organic aerosol formation through oxidative cloud processing, Atmos. Chem. Phys., 12, 7103-7116, https://doi.org/10.5194/acp-12-7103-2012, 2012.

Lim, Y. B., Tan, Y., and Turpin, B. J.: Chemical insights, explicit chemistry, and yields of secondary organic aerosol from $\mathrm{OH}$ radical oxidation of methylglyoxal and glyoxal in the aqueous phase, Atmos. Chem. Phys., 13, 8651-8667, https://doi.org/10.5194/acp-13-8651-2013, 2013.

Lin, P., Yu, J. Z., Engling, G., and Kalberer, M.: Organosulfates in Humic-like Substance Fraction Isolated from Aerosols at Seven Locations in East Asia: A Study by Ultra-High-Resolution Mass Spectrometry, Environ. Sci. Technol., 46, 13118-13127, https://doi.org/10.1021/es303570v, 2012.
Loeffler, K. W., Koehler, C. A., Paul, N. M., and De Haan, D. O.: Oligomer Formation in Evaporating Aqueous Glyoxal and Methyl Glyoxal Solutions, Environ. Sci. Technol., 40, 63186323, https://doi.org/10.1021/es060810w, 2006.

Mazzoleni, L. R., Ehrmann, B. M., Shen, X., Marshall, A. G., and Collett, J. L.: Water-Soluble Atmospheric Organic Matter in Fog: Exact Masses and Chemical Formula Identification by Ultrahigh-Resolution Fourier Transform Ion Cyclotron Resonance Mass Spectrometry, Environ. Sci. Technol., 44, 36903697, https://doi.org/10.1021/es903409k, 2010.

Mazzoleni, L. R., Saranjampour, P., Dalbec, M. M., Samburova, V., Hallar, A. G., Zielinska, B., Lowenthal, D. H., and Kohl, S.: Identification of water-soluble organic carbon in non-urban aerosols using ultrahigh-resolution FT-ICR mass spectrometry: organic anions, Environ. Chem., 9, 285-297, https://doi.org/10.1071/EN11167, 2012.

McNeill, V. F., Woo, J. L., Kim, D. D., Schwier, A. N., Wannell, N. J., Sumner, A. J., and Barakat, J. M.: Aqueous-Phase Secondary Organic Aerosol and Organosulfate Formation in Atmospheric Aerosols: A Modeling Study, Environ. Sci. Technol., 46, 80758081, https://doi.org/10.1021/es3002986, 2012.

Minerath, E. C. and Elrod, M. J.: Assessing the Potential for Diol and Hydroxy Sulfate Ester Formation from the Reaction of Epoxides in Tropospheric Aerosols, Environ. Sci. Technol., 43, 13861392, https://doi.org/10.1021/es8029076, 2009.

Minerath, E. C., Casale, M. T., and Elrod, M. J.: Kinetics Feasibility Study of Alcohol Sulfate Esterification Reactions in Tropospheric Aerosols, Environ. Sci. Technol., 42, 4410-4415, https://doi.org/10.1021/es8004333, 2008.

Minor, E. C., Steinbring, C. J., Longnecker, K., and $\mathrm{Ku}-$ jawinski, E. B.: Characterization of dissolved organic matter in Lake Superior and its watershed using ultrahigh resolution mass spectrometry, Org. Geochem., 43, 1-11, https://doi.org/10.1016/j.orggeochem.2011.11.007, 2012.

Mohnen, V. A. and Kadlecek, J. A.: Cloud chemistry research at Whiteface Mountain, Tellus B, 41, 79-91, https://doi.org/10.1111/j.1600-0889.1989.tb00127.x, 1989.

Nguyen, T. B., Laskin, A., Laskin, J., and Nizkorodov, S. A.: Direct aqueous photochemistry of isoprene high- $\mathrm{NO}_{x}$ secondary organic aerosol, Phys. Chem. Chem. Phys., 14, 9702-9714, https://doi.org/10.1039/C2CP40944E, 2012a.

Nguyen, T. B., Lee, P. B., Updyke, K. M., Bones, D. L., Laskin, J., Laskin, A., and Nizkorodov, S. A.: Formation of nitrogen- and sulfur-containing light-absorbing compounds accelerated by evaporation of water from secondary organic aerosols, J. Geophys. Res.-Atmos., 117, D01207, https://doi.org/10.1029/2011JD016944, 2012b.

Nozière, B., Ekström, S., Alsberg, T., and Holmström, S.: Radical-initiated formation of organosulfates and surfactants in atmospheric aerosols, Geophys. Res. Lett., 37, L05806, https://doi.org/10.1029/2009GL041683, 2010.

O’Brien, R. E., Laskin, A., Laskin, J., Rubitschun, C. L., Surratt, J. D., and Goldstein, A. H.: Molecular characterization of S- and N-containing organic constituents in ambient aerosols by negative ion mode high-resolution Nanospray Desorption Electrospray Ionization Mass Spectrometry: CalNex 2010 field study, J. Geophys. Res.-Atmos., 119, 1270612720, https://doi.org/10.1002/2014JD021955, 2014. 
Perri, M. J., Lim, Y. B., Seitzinger, S. P., and Turpin, B. J.: Organosulfates from glycolaldehyde in aqueous aerosols and clouds: Laboratory studies, Atmos. Environ., 44, 2658-2664, https://doi.org/10.1016/j.atmosenv.2010.03.031, 2010.

Pratt, K. A., Fiddler, M. N., Shepson, P. B., Carlton, A. G., and Surratt, J. D.: Organosulfates in cloud water above the Ozarks' isoprene source region, Atmos. Environ., 77, 231-238, https://doi.org/10.1016/j.atmosenv.2013.05.011, 2013.

Purohit, V. and Basu, A. K.: Mutagenicity of Nitroaromatic Compounds, Chem. Res. Toxicol., 13, 673-692, https://doi.org/10.1021/tx000002x, 2000.

Renard, P., Siekmann, F., Salque, G., Demelas, C., Coulomb, B., Vassalo, L., Ravier, S., Temime-Roussel, B., Voisin, D., and Monod, A.: Aqueous-phase oligomerization of methyl vinyl ketone through photooxidation - Part 1: Aging processes of oligomers, Atmos. Chem. Phys., 15, 21-35, https://doi.org/10.5194/acp-15-21-2015, 2015.

Riva, M., Da Silva Barbosa, T., Lin, Y.-H., Stone, E. A., Gold, A., and Surratt, J. D.: Chemical characterization of organosulfates in secondary organic aerosol derived from the photooxidation of alkanes, Atmos. Chem. Phys., 16, 11001-11018, https://doi.org/10.5194/acp-16-11001-2016, 2016.

Sagona, J. A., Dukett, J. E., Hawley, H. A., and Mazurek, M. A.: Sequential derivatization of polar organic compounds in cloud water using O-(2,3,4,5,6-pentafluorobenzyl)hydroxylamine hydrochloride, N,O-bis(trimethylsilyl)trifluoroacetamide, and gaschromatography/mass spectrometry analysis, J. Chromatogr. A, 1362, 16-24, https://doi.org/10.1016/j.chroma.2014.08.001, 2014.

Schindelka, J., Iinuma, Y., Hoffmann, D., and Herrmann, H.: Sulfate radical-initiated formation of isoprene-derived organosulfates in atmospheric aerosols, Faraday Discuss., 165, 237-259, https://doi.org/10.1039/C3FD00042G, 2013.

Schwab, J. J., Casson, P., Brandt, R., Husain, L., Dutkewicz, V., Wolfe, D., Demerjian, K. L., Civerolo, K. L., Rattigan, O. V., Felton, H. D., and Dukett, J. E.: Atmospheric Chemistry Measurements at Whiteface Mountain, NY: Cloud Water Chemistry, Precipitation Chemistry, and Particulate Matter, Aerosol Air Qual. Res., 16, 841-854, https://doi.org/10.4209/aaqr.2015.05.0344, 2016a.

Schwab, J. J., Wolfe, D., Casson, P., Brandt, R., Demerjian, K. L., Husain, L., Dutkiewicz, V. A., Civerolo, K. L., and Rattigan, O. V.: Atmospheric Science Research at Whiteface Mountain, NY: Site Description and History, Aerosol Air Qual. Res., 16, 827840, https://doi.org/10.4209/aaqr.2015.05.0343, 2016 b.

Stein, A. F., Draxler, R. R., Rolph, G. D., Stunder, B. J. B., Cohen, M. D., and Ngan, F.: NOAA's HYSPLIT Atmospheric Transport and Dispersion Modeling System, B. Am. Meteorol. Soc., 96, 2059-2077, https://doi.org/10.1175/BAMS-D-14$00110.1,2015$.

Stone, E. A., Yang, L., Yu, L. E., and Rupakheti, M.: Characterization of organosulfates in atmospheric aerosols at Four Asian locations, Atmos. Environ., 47, 323-329, https://doi.org/10.1016/j.atmosenv.2011.10.058, 2012.

Surratt, J. D., Gómez-González, Y., Chan, A. W. H., Vermeylen, R., Shahgholi, M., Kleindienst, T. E., Edney, E. O., Offenberg, J. H., Lewandowski, M., Jaoui, M., Maenhaut, W., Claeys, M., Flagan, R. C., and Seinfeld, J. H.: Organosulfate Formation in Biogenic
Secondary Organic Aerosol, J. Phys. Chem. A, 112, 8345-8378, https://doi.org/10.1021/jp802310p, 2008.

Surratt, J. D., Chan, A. W. H., Eddingsaas, N. C., Chan, M., Loza, C. L., Kwan, A. J., Hersey, S. P., Flagan, R. C., Wennberg, P. O., and Seinfeld, J. H.: Reactive intermediates revealed in secondary organic aerosol formation from isoprene, P. Natl. Acad. Sci. USA, 107, 6640-6645, https://doi.org/10.1073/pnas.0911114107, 2010.

Tan, Y., Carlton, A. G., Seitzinger, S. P., and Turpin, B. J.: \{SOA\}from methylglyoxal in clouds and wet aerosols: Measurement and prediction of key products, Atmos. Environ., 44, 52185226, https://doi.org/10.1016/j.atmosenv.2010.08.045, 2010.

Tao, S., Lu, X., Levac, N., Bateman, A. P., Nguyen, T. B., Bones, D. L., Nizkorodov, S. A., Laskin, J., Laskin, A., and Yang, X.: Molecular Characterization of Organosulfates in Organic Aerosols from Shanghai and Los Angeles Urban Areas by Nanospray-Desorption Electrospray Ionization High-Resolution Mass Spectrometry, Environ. Sci. Technol., 48, 10993-11001, https://doi.org/10.1021/es5024674, 2014.

Tfaily, M. M., Podgorski, D. C., Corbett, J. E., Chanton, J. P., and Cooper, W. T.: Influence of acidification on the optical properties and molecular composition of dissolved organic matter, Anal. Chim. Acta, 706, 261-267, https://doi.org/10.1016/j.aca.2011.08.037, 2011.

Tfaily, M. M., Hodgkins, S., Podgorski, D. C., Chanton, J. P., and Cooper, W. T.: Comparison of dialysis and solid-phase extraction for isolation and concentration of dissolved organic matter prior to Fourier transform ion cyclotron resonance mass spectrometry, Anal. Bioanal. Chem., 404, 447-457, https://doi.org/10.1007/s00216-012-6120-6, 2012.

Tfaily, M. M., Hamdan, R., Corbett, J. E., Chanton, J. P., Glaser, P. H., and Cooper, W. T.: Investigating dissolved organic matter decomposition in northern peatlands using complimentary analytical techniques, Geochim. Cosmochim. Ac., 112, 116-129, https://doi.org/10.1016/j.gca.2013.03.002, 2013.

Tfaily, M. M., Chu, R. K., Tolić, N., Roscioli, K. M., Anderton, C. R., Paša-Tolić, L., Robinson, E. W., and Hess, N. J.: Advanced Solvent Based Methods for Molecular Characterization of Soil Organic Matter by HighResolution Mass Spectrometry, Anal. Chem., 87, 5206-5215, https://doi.org/10.1021/acs.analchem.5b00116, 2015.

van Pinxteren, D., Fomba, K. W., Mertes, S., Müller, K., Spindler, G., Schneider, J., Lee, T., Collett, J. L., and Herrmann, H.: Cloud water composition during HCCT-2010: Scavenging efficiencies, solute concentrations, and droplet size dependence of inorganic ions and dissolved organic carbon, Atmos. Chem. Phys., 16, 3185-3205, https://doi.org/10.5194/acp-16-3185-2016, 2016.

Yasmeen, F., Vermeylen, R., Szmigielski, R., Iinuma, Y., Böge, O., Herrmann, H., Maenhaut, W., and Claeys, M.: Terpenylic acid and related compounds: precursors for dimers in secondary organic aerosol from the ozonolysis of $\alpha$ - and $\beta$-pinene, Atmos. Chem. Phys., 10, 9383-9392, https://doi.org/10.5194/acp10-9383-2010, 2010.

Yu, L., Smith, J., Laskin, A., Anastasio, C., Laskin, J., and Zhang, Q.: Chemical characterization of SOA formed from aqueousphase reactions of phenols with the triplet excited state of carbonyl and hydroxyl radical, Atmos. Chem. Phys., 14, 1380113816, https://doi.org/10.5194/acp-14-13801-2014, 2014. 
Yu, L., Smith, J., Laskin, A., George, K. M., Anastasio, C., Laskin, J., Dillner, A. M., and Zhang, Q.: Molecular transformations of phenolic SOA during photochemical aging in the aqueous phase: competition among oligomerization, functionalization, and fragmentation, Atmos. Chem. Phys., 16, 4511-4527, https://doi.org/10.5194/acp-16-4511-2016, 2016.

Zhang, X., Lin, Y.-H., Surratt, J. D., Zotter, P., Prévôt, A. S. H., and Weber, R. J.: Light-absorbing soluble organic aerosol in Los Angeles and Atlanta: A contrast in secondary organic aerosol, Geophys. Res. Lett., 38, L21810, https://doi.org/10.1029/2011GL049385, 2011.

Zhang, X., Lin, Y.-H., Surratt, J. D., and Weber, R. J.: Sources, Composition and Absorption Ångström Exponent of Lightabsorbing Organic Components in Aerosol Extracts from the Los Angeles Basin, Environ. Sci. Technol., 47, 3685-3693, https://doi.org/10.1021/es305047b, 2013.

Zhao, J., Levitt, N. P., Zhang, R., and Chen, J.: Heterogeneous Reactions of Methylglyoxal in Acidic Media: Implications for Secondary Organic Aerosol Formation, Environ. Sci. Technol., 40, 7682-7687, https://doi.org/10.1021/es060610k, 2006.
Zhao, Y., Hallar, A. G., and Mazzoleni, L. R.: Atmospheric organic matter in clouds: exact masses and molecular formula identification using ultrahigh-resolution FT-ICR mass spectrometry, Atmos. Chem. Phys., 13, 12343-12362, https://doi.org/10.5194/acp-13-12343-2013, 2013. 